\title{
El principio acusatorio en el modelo adversarial colombiano. Análisis en torno a su aplicación
}

Ana Milena Díaz González*

\section{Resumen}

El trabajo se ocupa de analizar cómo en el sistema penal de corte acusatorio vigente el dogma del principio acusatorio carece de estructura aplicable; muestra cómo, con extrañeza, se emplea ese postulado pese a que está concebido de cara a instituciones que, justamente, hacían parte del sistema inquisitivo derogado. Así las cosas, se busca poner en evidencia de qué manera tales matices terminaron por desnaturalizar un diseño que prometía solucionar los problemas más importantes del derecho procesal penal y no lo logró.

\section{Palabras Clave}

Código de Procedimiento Penal, modelo adversarial, modelo inquisitivo, principio acusatorio, sistema penal.

\section{Introducción}

Colombia, pese a los intentos por garantizar la efectividad del modelo mixto de tendencia inquisitiva acogido desde el año 2000 mediante la expedición de la Ley 600 de ese año, optó más bien y de forma abrupta por cambiar su sistema procesal. Por ello, implantó un nuevo patrón procesal en el cual se han depositado todas las esperanzas de cara a terminar con la inconformidad de la sociedad, en relación con los instrumentos legales existentes para combatir la delincuencia; no obstante, debe decirse, muchas han sido las dudas

${ }^{*}$ Maestra en Derecho de la Universidad Sergio Arboleda. 
suscitadas alrededor de la esencia, fines y formas de ese nuevo diseño procesal.

Para dar ese paso, el Acto Legislativo 03 de 2002 -que modificó en esta materia la Constitución de 1991 en su artículo 250-introdujo al ordenamiento interno el llamado sistema penal acusatorio, que se desarrolló y acogió legislativamente a través de la promulgación de ley 906 de 2004 o nuevo Código de Procedimiento Penal. Este modelo procesal trajo consigo el principio acusatorio que, en buena medida, prevé un esquema adversativo del cual se ha ocupado la doctrina procesal en plan de señalar sus diversas características, de tal manera que la estructura del mismo se haga más inteligible.

Por supuesto, la intención era introducir un diseño que permitiera aligerar los procedimientos, pero éste si bien no ha fracasado, ha sido objeto de algunas modificaciones que a juicio de la judicatura y de algunos críticos eran necesarias para satisfacer las expectativas del país. Sin embargo, dichas transformaciones han terminado por desquiciar el esquema en cuanto a la aplicación del principio acusatorio que, pese a ser concebido de una determinada forma, se ha desnaturalizado a lo largo de la implantación del sistema.

Inicialmente, tanto el modelo como el principio fueron concebidos con una visión acusatoria, que se denominó como adversarial o de partes, previa aceptación de que no se trataba de un sistema acusatorio puro sino de uno adversarial con un proceso penal modulado. Esto lo muestra el hecho de que se haya aceptado la participación de actores en el esquema procesal que en las legislaciones de otros países no se admiten, con lo cual se modifica de forma negativa la visión del principio acusatorio y, por ende, la concepción del proceso penal.

Con miras a ingerir en ese debate, esta aportación académica se ocupa del estudio de esos matices que, aplicados al modelo adversativo y al principio acusatorio, permiten concluir que el sistema introducido si bien responde a las expectativas y necesidades del país, no se corresponde con el patrón acogido en diversas latitudes, razón por la cual su estructura sólo funciona en el país.

De esta manera y para un mejor entendimiento del asunto a continuación se exponen, en primer lugar, las pesquisas preliminares de la investigación, de tal suerte que se delimita con claridad el objeto de estudio, los objetivos, el estado del arte, el marco teórico y la metodología de trabajo empleada. En segundo lugar, se discurre 
sobre el principio acusatorio en el modelo adversarial colombiano, con hincapié en su aplicación; en tercer lugar, se destina un acápite a las conclusiones; $y$, para terminar, se consigna la bibliografía consultada.

\section{El Proyecto de investigación}

Desde la promulgación e implantación paulatina de la ley 906 de 2004, ha cobrado gran importancia en este andamiaje procesal el llamado principio acusatorio que, con toda razón, es considerado por los estudiosos como el pilar fundamental de la estructura del proceso penal concebido por esa normatividad. En virtud de ese axioma se entiende que existe una clara división de funciones entre la acusación y el juzgamiento, en cabeza de un fiscal y de un juez -que en el sistema federal norteamericano corresponde al juradoquienes tienen como rol primordial presentar la acusación y juzgar al acusado. Por ello, la tarea del juez se tiene que sustentar en la más absoluta imparcialidad de la cual se infiere su neutralidad, fruto de lo cual es la prohibición de decretar la práctica de pruebas diferentes a las solicitadas por la fiscalía y la defensa.

En ese contexto, la presente investigación busca precisar si el principio acusatorio es objeto de plena observancia y aplicación en el proceso penal hoy existente, en especial en lo atinente a la función acusatoria de la fiscalía, el rol de las partes e intervinientes en el proceso y el papel activo o pasivo del juez en las lides probatorias en el trámite. Se busca, por ello, demostrar que el postulado en estudio es uno de los pilares fundamentales del proceso penal que delimita los deberes de una fiscalía cuya función primordial radica en acusar, a la vez que garantiza el equilibrio de fuerzas en el proceso y sin injerencias probatorias oficiosas del juez que pudieran desnaturalizar el sistema.

Con tales miras se hace un examen de la Constitución Política de Colombia, del entramado legislativo plasmado en la ley 906 de 2004, de la producción jurisprudencial de las altas cortes sobre la materia y, por supuesto, del derecho comparado. De allí que el marco teórico tenga el enfoque propio de la concepción positivista en la medida en que se busca examinar la forma como el citado axioma ha sido plasmado en el ordenamiento jurídico, de tal forma que se pueda ahondar en los componentes característicos del precepto axiológico y evaluar su correspondencia con la función acusatoria del fiscal y, como es natural, con los roles desempeñados por las demás partes e intervinientes en el desarrollo del proceso, concretamente en el juicio. 


\section{Planteamiento del problema}

El asunto jurídico objeto de indagación en el presente trabajo se concreta en la siguiente pregunta: ¿en el proceso penal colombiano se aplica, de verdad, el principio acusatorio? Para responder a ese interrogante, debe recordarse que la pretensión de los reformadores de 2004 fue implantar un sistema de procedimental penal que, ya desde su análisis y contextualización, pudiera ser concebido como una respuesta a las necesidades del país, aunque cimentado en unos pilares fundamentales (Colombia, Congreso de la República, Acto Legislativo 03, 2002, p. 1-138). Uno de ellos, por supuesto, fue el principio acusatorio que, se traduce en la división de las funciones de acusación y juzgamiento entre la Fiscalía General de la Nación y los jueces. De igual manera y dada su naturaleza, ese axioma conlleva la prohibición para que el juez decrete pruebas de oficio, pues se busca mantener el equilibrio entre las partes (fiscalía y defensa), por lo que cualquier intervención en iniciativas probatorias de otro sujeto diferente a ellas, muta la concepción primigenia de la estructura acusatoria propia del proceso (Bernal y Montealegre, 2013, p. 196-197).

Se pretende entonces, analizar la estructura procesal y las facultades de las partes e intervinientes dentro del proceso mismo, para lo cual se debe abordar la ley contentiva de este andamiaje con sus respectivas reformas, fruto de la actividad de legisladores, jueces y doctrinantes; sin que ello sea óbice para auscultar los sistemas penales foráneos, a fin de comprender los lineamentos del sistema dentro de una concepción no pura, pero si determinada, para entenderlo y poder establecer si en Colombia, efectivamente, al traer y adecuar el sistema, se logró incorporar sus componentes esenciales y determinar si en la actualidad el principio se mantiene incólume en la estructura del proceso penal.

\section{Objetivos}

Con esta exploración académica se persiguen dos tipos de cometidos, como se muestra a continuación.

Objetivo general. Analizar si en el desarrollo del sistema penal adversarial colombiano el principio acusatorio es aplicado.

Objetivos específicos. Son los siguientes:

- Establecer el significado del principio acusatorio de manera independiente, en el contexto del proceso penal en Colombia. 
- Analizar las atribuciones de las partes e intervinientes en el proceso penal.

- Ilustrar la concepción del principio acusatorio de algunos países que adoptaron el sistema penal acusatorio.

- Concretar la posición del juez desde el punto de vista probatorio en el proceso penal.

\section{Estado del arte}

El principio acusatorio se define como una de las piedras angulares del llamado sistema penal acusatorio, considerado a la vez como el verdadero proceso penal (Gómez, 2003a, p. 74), articulado por tres componentes (Montero, 1994, p. 537). El primero de ellos, es el ejercicio de la acción penal, la cual se encuentra en cabeza de un ente acusador que en el proceso penal nuestro le corresponde a la Fiscalía General de la Nación (Acto Legislativo 03 de 2002, que modificó el art. 250 de la Constitución Política). En segundo término, se caracteriza por la separación de las funciones de acusación y juzgamiento, por lo cual aquel que acusa nunca puede ser el que juzgue; de esta manera, se tiene que todo proceso en el que se dé plena observancia al principio acusatorio, debe contar con que quien acusa no juzga y viceversa, de tal suerte que se garantice total independencia e imparcialidad al momento de juzgar los hechos objeto de investigación.

Por último, como tercer elemento constitutivo del principio, se tiene que quien juzga, llámese juez, jurado o tribunal especializado, debe estar desprovisto de cualquier conocimiento previo a su actuación. Así pues, el ejercicio de la función juzgadora debe estar colmada de la más absoluta imparcialidad, del enteramiento propio de los hechos a través de las pruebas y de los argumentos jurídicos de los contendores, fiscalía y defensa, los cuales deben ser apreciados en la audiencia pública; de tal manera que, una vez concluido el debate probatorio se emita un fallo absolutorio o condenatorio (Gómez, 2003a, p. 74).

Sobre estas problemáticas discurre con amplitud la doctrina de diversas latitudes, aunque se destacan los desarrollos españoles, italianos y alemanes. En el contexto latinoamericano, son abundantes las construcciones argentinas, aunque también se ocupan del asunto los estudiosos chilenos, mexicanos, peruanos, panameños, hondureños, costarricenses y, por supuesto, los colombianos. Igual sucede con las construcciones jurisprudenciales de los diversos países y, 
como es obvio, con las normatividades foráneas. A ello se destinan diversos apartados en el acápite segundo de este trabajo.

\section{El marco teórico.}

Los aspectos generales en torno a las diversas concepciones que alumbran el principio acusatorio, son los que se señalan a continuación.

¿Qué es el principio acusatorio y cuáles son sus elementos? Lo primero que debe preguntarse es qué debe entenderse por principio acusatorio, interrogante cuya respuesta resulta de gran trascendencia a la hora de estructurar lo que se conoce como tal.

A este respecto, algunos autores (en este sentido Bovino, 2005, p. 37; Bovino, 1998, p. 10 y ss.; Moreno, Cortés y Gimeno, 2003, 218; Gimeno, 1981, p. 190-192; Vásquez, 1984, p. 373-418; Montero, 1992, p. 775-788; Montero,1994, p. 537; Armenta Deu, 1995, p. 39-111; Asencio, 1991, p. 17 y ss.; Burgos, 2005, p. 44; Meza, 2009, p. 195-213; Gómez, 2003a, p. 74 y ss.) consideran que el postulado examinado se caracteriza por la división de funciones de acusación y juzgamiento, la primera a cargo de una persona no identificable como el juzgador; la imparcialidad del juzgador y la necesidad de la primera para que exista la segunda (Abad, 2000; Ortego, 2007, p. 57; Arbulú, 2006), por lo cual es prohibido condenar por los hechos que no correspondan a la acusación. No obstante, hay quienes le dan a este postulado otro alcance pues creen que él se concreta es en la prohibición de reformar en peor (Baumann, 1986, p. 48-49), mientras que para otros se estructura en la prueba de cargo por parte del Estado y en la igualdad de armas entre las partes (Herrera, 2005).

Por supuesto, es menester analizar si tales elementos se encuentran incluidos en el principio acusatorio asumido y aplicado por el derecho nacional a fin de concluir si el axioma acogido se corresponde o no al visionado en el modelo adversarial.

¿Es la imparcialidad judicial elemento del principio acusatorio? En relación con este tópico, resulta de vital importancia señalar que dicha característica puede tenerse como mal denominada. Esto si se tiene en cuenta que al principio acusatorio lo caracteriza es la neutralidad probatoria no la imparcialidad judicial, pues ella es el escenario ideal para la administración de justicia y, la neutralidad, debe concebirse como la pasividad probatoria del juzgador (Palomares, 2009, p. 66). 
En Colombia, la discusión en relación con la neutralidad o no actividad oficiosa ha sido analizada por la Corte Constitucional y la Corte Suprema de Justicia. La primera (Corte Constitucional, Sentencia C-396, 2007) descarta la oficiosidad del decreto de pruebas porque se presume que esta intervención activa por parte del juez, termina por pervertir la imparcialidad que le debe caracterizar; además, desequilibra el sistema, inclinando la balanza de un lado, ya sea para la fiscalía o la defensa. Y, la segunda (Corte Suprema de Justicia, Sala de casación Penal, radicado: 24468, treinta de marzo de 2006), al considerar que en defensa de los fines del proceso penal, verdad y justicia, el juez puede decretar pruebas de oficio.

No obstante, se ha dicho que el juez de control de garantías puede decretar pruebas de oficio en la audiencia de solicitud de imposición de medida de aseguramiento (Corte Constitucional, Sentencia C-591, 2005).

¿Existe autonomía del acusador para acusar? Así mismo, para abordar el otro elemento que perfila el marco teórico, sobre la potestad de autonomía del ente acusador en el ejercicio de la acción penal se cuestiona puntualmente la problemática descrita en los artículos 332, 334 y 335 del Código de Procedimiento Penal. Éste último, contempla la posibilidad de que así se hayan analizado ya los hechos materia de investigación y se haya determinado que no se puede continuar con el ejercicio de la acción, la fiscalía lo pueda solicitar pues se restituye el término y el juez pueda rechazar la solicitud de preclusión.

¿Hay injerencia de las partes en el equilibrio del modelo adversarial? Sobre la igualdad de armas o mejor de oportunidades, la jurisprudencia ha dicho que la víctima puede solicitar la práctica de pruebas, dejando de lado el equilibrio predicado para el proceso y, por supuesto, echando por el piso las bases del sistema penal acusatorio (Corte Constitucional, Sentencia C-209, 2007). Por ello, se deberá abordar a fondo la participación de las partes en el proceso penal para así concluir si se mantiene el equilibrio de las partes (fiscalía y defensa) o si, por el contrario, se advierte que el sistema se desequilibra por la interacción de otros sujetos que terminan por desdibujar el tinte acusatorio.

\section{La metodología de la investigación.}

La investigación ha supuesto una ardua búsqueda documental, con base en la cual se ha hecho un estudio crítico de la normatividad vigente, de la doctrina y de la jurisprudencia de las altas cortes. 


\section{Los sistemas procesales penales}

Para un mejor estudio del principio acusatorio como elemento del sistema penal acusatorio, resulta necesario abordar los modelos penales tradicionales (Vélez, 1956, 9 y ss.; Benabentos, 2005, p. 1 y ss.), el inquisitivo y el acusatorio o adversarial, puesto que el principio suele ser confundido con el sistema (Gómez, 2008, p. 21 y ss.; Rodríguez 2013, p. 647-648), lo cual es erróneo, pues el acusatorio es la especie del sistema anglosajón.

\section{Los modelos tradicionales.}

Como origen y cuna del principio acusatorio se suele citar la Grecia antigua en tiempos de Solón, (Vélez, 1956, p. 15) donde por primera vez -al acoger la Política Criminal de la época- aquel gobernante escribió una ley en la que habilitó a sus ciudadanos para que, en precisos escenarios, pudieran iniciar acciones frente a infracciones cometidas a otros, sin importar que parecieran individuales y no colectivas, pues se entendía que una ofensa a un integrante de la polis lo era para ésta (Vlastos, 1946). Por ello, tiene razón un sector de la doctrina para el cual no necesariamente se debe concluir que la aparición en escena del principio acusatorio aconteció con el sistema continental instaurado por los ingleses al bajar del barco proveniente de Inglaterra, considerando su origen mucho tiempo después. (Díez-Picazo, 1997, p. 295).

En lo que al sistema inquisitivo respecta, recuérdese, debe decirse que él se remonta a las cruzadas de la Europa de la Edad Media, siglos XII y XIII (Vélez, 1956, p. 79). Con posterioridad, el cristianismo a través de la iglesia católica, introdujo los tribunales de la inquisición, los cuales fueron suprimidos en el reinado de Napoleón (Tomás y Valiente, 1980, p. 41-60); pero llegaron a América con la compañía conquistadora que concentró en la Iglesia los juicios inquisidores, como bien lo advierte Maier (1996, p. 329). Penas como castigos religiosos, prisión o muerte, dependían de la colaboración del investigado, quien podía tener una sanción leve consistente en un sinnúmero de rezos en los casos en que acudía por iniciativa propia a la Iglesia a confesar su falta, o podía ser condenado a muerte si peleaba su inocencia.

En términos generales se acepta la existencia de un sistema inquisitivo caracterizado por: la dirección judicial del proceso, pues 
era el juez el que dirigía, investigaba y juzgaba; la bipartición del proceso, pues existían dos etapas, una preliminar de investigación y el juicio o la causa; predominaba el secreto en el proceso, pues todas las actuaciones se consideraban reservadas. De igual manera, primaba el escriturismo; existía la tarifa legal, en el sentido de que la confesión era la prueba reina, gracias a lo cual se tornaba el proceso en abreviado y la tortura era el medio más idóneo para lograr la confesión de culpabilidad; y la declaración de inocencia era nula, pues se buscaba la verdad real, por tanto no era admisible la presunción de inocencia. (Tomás y Valiente, 1976).

El sistema procesal inquisitivo observa tres principios, i) el non bis in idem, cuyo origen se encuentra en el sistema; ii) el de doble instancia, que permite evitar abusos, garantiza la seguridad jurídica y el respeto del de cosa juzgada; y iii) el in dubio pro reo, cuya vigencia fue adoptada al inquisitivo luego del reconocimiento de garantías al procesado (Ordoñez, Cano, 2003, p. 77).

Posteriormente, con la revolución francesa, el modelo inquisitivo ortodoxo fue cambiando al reconocer al acusado algunos derechos individuales, dejando de ser el objeto del proceso. Se abolió la tortura; se abrió la posibilidad del juicio oral, público y contradictorio; se introdujo la separación de poderes en el proceso; se creó la figura del Ministerio Público, con la función de acusar y se incorporó el jurado de conciencia. Todas estas modificaciones renombraron el sistema inquisitivo como mixto, el cual fue conocido como modelo inglés, siendo Francia el país pionero a través de la expedición del Código Napoleónico de 1808, transformación que luego fue regada a lo largo y ancho del continente Europeo (Ferreiro, 2010).

Desde luego, los conceptos acusatorio e inquisitivo merecen un estudio juicioso que permita aclarar las estructuras de los sistemas anglosajón y continental. El primero, utilizó dos estructuras como lo afirma Langbein, (2003): un proceso penal para legos originario del siglo XV y otro para profesionales, capturado por juristas del siglo XVIII (p. 147). Éste último caracterizado por el silencio del acusado, la asistencia letrada (donde confluyen los papeles de protección y exposición testimonial a favor del acusado), la necesidad de acusación, juicio ante jurado, condena con pruebas de cargo del acusador (donde la defensa podía esperar los argumentos de cargo y guardar silencio), procedimiento en el que el contrainterrogatorio 
era característico del adversativo y se evidenciaron las reglas de exclusión probatoria (Guerrero, 2011, p. 4).

En el proceso penal de legos, el principio de la no autoincriminación no tenía cabida, pues éste a pesar de ser una institución propia del derecho romano, se contrarrestaba con el juramento en nombre de Dios para responder las preguntas del jurado por parte del acusado, quien previamente debía aceptar una cuota de culpabilidad y, en el evento de negarse a jurar, implicaba valoración en su contra.

Tal vez por ello, se considera que el sistema inquisitivo remonta sus orígenes al absolutismo, posterior a la reagrupación de la corona frente a la división de la época feudal. En la lucha por el imperio cristiano en la Europa continental, la inquisición ejercía la acusación (atribución que en la época feudal le correspondía al ofendido y el acusado perdía su personería jurídica). El modelo se caracterizaba por la investigación de oficio, secreta con marcada escrituración y jueces colegiados (eclesiásticos) para el cual el acusado era el objeto del proceso. La búsqueda de la verdad se justificó, como lo menciona Maier (1996), mediante la introducción de la tortura, no sólo del acusado sino de los testigos -esclavos o indignos- que no podían prestar juramento, al igual que la prisión que era necesaria para el proceso (p. 288).

En relación con la competencia judicial, se estableció que era dada por el lugar donde ocurría el hecho, a lo que se llamó jurisdicción real en contraposición a los intereses del poder feudal ya desplazado. El poder jurisdiccional estaba en cabeza del rey, quien lo delegó en los tribunales y funcionarios organizados jerárquicamente, razón por la cual las decisiones eran apelables. La prueba testimonial se convirtió en la que fuese necesaria para apuntalar la sentencia judicial. La valoración legal de la prueba como semiplena prueba o plena prueba era utilizada. Además, la presunción de culpabilidad ante la ausencia de pruebas testimoniales o indiciarias permitía la tortura para que el acusado confesara (Maier, 1996).

En el viejo continente el sistema inquisitivo se fue sembrando en los modelos de enjuiciamiento, así, en la España del siglo XIII se estableció a través de Las Cruzadas, pero con la adopción de dos principios cardinales: el in dubio pro reo y el ne bis in ídem (Maier, 1996, p. 301). Alemania, recuérdese, lo adoptó en 1532 con el Código Carolina (la llamada Constitutio Criminalis Carolina) fruto del derecho 
canónico; a su turno, en Francia se abrió paso con la Ordenanza de 1254. También Italia, después de la invasión de los bárbaros, aplicó el derecho germano. Con posterioridad, el sistema inquisitivo cobró vigencia con similares características que las desarrolladas en esos países en el resto de Europa donde terminó por generalizarse (Maier, 1996, p. 310).

En América, partiendo de la premisa de no contar con otro modelo en razón a la imposición de la cultura de un continente a otro, la conquista (sobre todo la española) trajo consigo el sistema inquisitivo, regido por el derecho colonial y las Siete Partidas de Alfonso X El Sabio. Por ello, el poder judicial estaba radicado en el rey, en quien confluían además las facultades de administrar y legislar, aunque sus decisiones podían ser recurridas hasta cuatro veces; no obstante y por vía excepcional, se aceptó la delegación jerárquica, el procedimiento se caracterizaba por ser escrito y secreto, se permitía la tortura y la investigación era de oficio y pública (Maier, 1996, p. 328).

Producto del inconformismo de los filósofos e ideólogos del siglo XVIII -entre los que se destacaron Montesquieu, Beccaria y Voltaire-, se inició la transformación del sistema de enjuiciamiento penal. De las resultas del derecho romano republicano y el derecho practicado en Inglaterra, se dio paso a los procedimientos orales, publicidad de los debates, libertad de la defensa y juicio ante jurados (Benabentos, 2005, p. 103).

Montesquieu, Voltaire y Beccaria, concibieron el proceso con el ejercicio libre de la defensa, sin tortura, con la presencia de tribunales populares legos y accidentales-siendo posible recurrir al jurado en caso de sospecha de parcialidad-(Vélez, 1956, p. 117), dotado de un juicio oral y público, con certeza para condenar in dubio pro reo-; es más, en contraposición al acusatorio puro y a la acusación popular se defiende la persecución penal pública en cabeza del ministerio público y se rechaza la denuncia anónima, amén de que se abre paso a la libre valoración de la prueba desplazando el sistema de la tarifa legal; es más, se llegó, salvo por Beccaria, a cuestionar la privación de la libertad del acusado en la investigación (Maier, 2005, p. 336).

En lo que a América Latina concierne, y ya adentrados en el siglo XX, debe decirse que el origen del sistema mixto en Argentina se retrotrae al Código Procesal de la Provincia de Córdoba en 1939 
(Vélez, p.182); se empezaron, pues, a adoptar los lineamientos de los códigos procesales penales italianos (1913) y la Ley de Enjuiciamiento criminal española de 1882 y de Costa Rica con la sanción en 1973 (Maier, 1996, p. 381). Ese sistema, ha dicho la doctrina, se caracteriza por: a) la disimilitud de las funciones de instrucción, acusación y juzgamiento; b) la aceptación del acusatorio, traducido en que sin acusación no hay juicio, no hay condena, se permite en algunos estados que el juez no actúe de oficio; c) la necesidad de una investigación como presupuesto para el juicio; d) el juicio debe ser público y contradictorio y las pruebas valoradas libremente por el tribunal (no existe tarifa legal), de acuerdo a la convivencia o con sujeción a las reglas de la sana crítica y las máximas de la experiencia; e) se acepta que el tribunal se conforme por un jurado de escabinos o con jueces profesionales y técnicos; y, f) se admite una relativa vinculación del tribunal o juez a las pretensiones de las partes (Martínez, 1992).

De forma errada se considera que el sistema acusatorio venía asociado a la acción privada, como era el caso de Grecia o Roma donde se admitía la heterotutela como forma de solicitar la efectividad de sus derechos sin intervención del Estado (Guerrero, 2009, p. 98). Sin embargo, el sistema acusatorio presupone la acción del Estado al considerar el delito como un perjuicio público, y el Estado está interesado en que no se reproduzca al interior del colectivo social (Diez-Picazo, 2000, p. 36); en los sistemas acusatorios puros, recuérdese, la acción es pública y el Ministerio Público es quien la ejercita (Guerrero, 2009, p. 99).

De lo anterior se puede colegir que el sistema acusatorio es aquel en el que: a) la facultad de acusación es de todo ciudadano y aquella es presupuesto del juicio, la cual debe ser formulada por persona diferente al juez; b) éste no puede actuar de oficio; c) el juez es el pueblo, las sentencias son proferidas por el jurado, por tanto son inapelables; d) no se permite la doble instancia; e) la regla general es la libertad del acusado hasta que se demuestre su culpabilidad; f) se admite la igualdad de armas entre acusador y defensa; $y$, g) se limita el fallo a los hechos alegados y probados en el juicio (Guerrero, 2009, p. 105-107).

Desde luego, pese a lo dicho, parece evidente que no todos los estados de derecho adoptaron el sistema acusatorio, lo que no implica aceptar que un proceso de otro modelo no pueda ser llamado como tal, o, peor aún, llegar a sostener -como lo hace 
Gómez (2008) - que el proceso acusatorio es el único proceso o que el proceso inquisitivo es un no proceso (p. 74). Por tanto, puede advertirse que existen algunas diferencias entre los sistemas tradicionales y el acusatorio, una de ellas radica en considerar que el inquisitivo califica al procesado como el objeto del ius puniendi y no como titular de derechos y garantías procesales, mientras que el acusatorio reconoce al acusado como sujeto de derecho con garantías sustanciales y penales, contenidas en el debido proceso, los cuales constituyen un límite al poder punitivo del estado (Pfeffer, 2001).

Ahora bien, teniendo en cuenta las diferencias entre los dos sistemas, puede hacerse la siguiente tabla para contrastar sus notas más salientes (Cuéllar, 2001, p. 313).

Tabla 1.

Notas de los sistemas inquisitivo y acusatorio

\begin{tabular}{|c|c|}
\hline SISTEMA INQUISITIVO & $\begin{array}{c}\text { SISTEMA ACUSATORIO O } \\
\text { ADVERSARIAL }\end{array}$ \\
\hline IDENTIDAD DE QUIEN INVESTIGA Y JUZGA & $\begin{array}{l}\text { SEPARACIÓN DE FUNCIONES DE } \\
\text { INSTRUCCIÓN Y CAUSA }\end{array}$ \\
\hline $\begin{array}{l}\text { PRIVACIÓN DE LA LIBERTAD DEL PROCESADO } \\
\text { ERA LA REGLA GENERAL }\end{array}$ & $\begin{array}{l}\text { LIBERTAD DEL PROCESADO COMO REGLA } \\
\text { GENERAL }\end{array}$ \\
\hline INVESTIGACIÓN SECRETA Y RESERVADA & PUBLICIDAD EN EL JUICIO \\
\hline PROCEDIMIENTO ESCRITO & PROCEDIMIENTO ORAL \\
\hline $\begin{array}{l}\text { JUZGADOR CON FACULTADES PROBATORIAS } \\
\text { OFICIOSAS }\end{array}$ & $\begin{array}{l}\text { JUZGADOR CON PROHIBICIÓN DE FACULTAD } \\
\text { OFICIOSA PROBATORIA }\end{array}$ \\
\hline $\begin{array}{l}\text { PRINCIPIO DE PERMANENCIA DE LAS } \\
\text { PRUEBAS DURANTE LA INVESTIGACIÓN Y } \\
\text { JUICIO }\end{array}$ & $\begin{array}{l}\text { PRINCIPIO DE INMEDIACIÓN DE LOS MEDIOS } \\
\text { DE PRUEBA }\end{array}$ \\
\hline JUZGAMIENTO SIN ACUSACIÓN & ACUSACIÓN COMO PRESUPUESTO DEL JUICIO \\
\hline LIMITACIÓN DE GARANTÍAS DEL PROCESADO & $\begin{array}{l}\text { PREVALENCIA DEL DEBIDO PROCESO } \\
\text { DERECHO FUNDAMENTAL Y GARANTÍA } \\
\text { PROCESAL DEL ACUSADO }\end{array}$ \\
\hline DERECHO A LA DOBLE INSTANCIA & DECISIÓN SIN POSIBILIDAD DE RECURRIR \\
\hline
\end{tabular}

No obstante, existen diferencias coyunturales entre los sistemas penales que históricamente han cobrado vigencia; una de ellas, es la que toca con la naturaleza del delito que, desde la mirada del sistema acusatorio, es considerado un perjuicio público en franca rivalidad con los sistemas antiguos o inquisitivos, para los cuales siempre se contempló como un agravio privado a la víctima (DíezPicazo, 2000, p. 36). 
En fin, para materializar la investigación de las conductas delictivas, debe decirse que el sistema acusatorio concibe la figura del Ministerio Fiscal como órgano detentador del poder punitivo, estamento no concebido en los sistemas antiguos, de tal manera que tanto la estructura (Ministerio) como el fin (investigación de delito) son públicos (Guerrero, 2009, p. 99). Ahora bien, en los sistemas antiguos no acusatorios, existía una intervención mínima o nula del Estado en la investigación de los delitos, al entenderse como causa privada; y, en razón a ello, no se aplicaban los conceptos de imparcialidad y neutralidad (Guerrero, p. 99), situación diferente en presencia del modelo acusatorio, en el que se pretende la materialización del primero al dividir las funciones de acusación y de juzgamiento y en el que la vocación de ser neutral más allá de serlo, debe parecerlo (Guerrero, 2009, p. 55).

\section{El principio acusatorio.}

La doctrina -tanto nacional como extranjera-, que es fuente primordial del Derecho, ha contribuido en muy buena medida a la definición conceptual del principio acusatorio (Aguilera De Paz, 1923, p. 10 y ss.; Gómez y Herce, 1959, p. 116 y ss.), al señalar sus elementos de manera clara, lo que brinda una estructura transparente que facilita su hallazgo en el proceso penal. No obstante, hay quienes opinan que según el sistema en el que se desarrolle, anglosajón o continental, él tiende a ser el resultado de una práctica procesal o del cúmulo de normas que lo incluyen como derecho (Alliaud, 2001). Otro tanto cabe decir de las plurales construcciones jurisprudenciales y legislativas hechas por los diversos países que, sin duda, han alimentado esta construcción conceptual hasta límites insospechados.

Una breve mirada al derecho comparado, con un énfasis final en el derecho nacional, así lo confirma. En efecto, desde la perspectiva alemana, Baumann señala que el postulado acusatorio admite la división de las atribuciones de instrucción y la causa a cargo de dos sujetos diferentes, con lo que se garantiza la imparcialidad del operador jurídico, en el entendido de que: a) quien investiga -Ministerio Público- es un órgano público autónomo dispar desde el punto de vista orgánico del juzgador; $y, b$ ) el acusado deja de ser el objeto del derecho procesal para convertirse en un sujeto (1986, p. 48-49).

En esa misma dirección son de trascendencia los planteos de Roxin (2000) quien, al calificar el sistema vigente en su país como 
regido por el principio acusatorio 'soberanamente' formal, señala que en virtud del mismo la apertura de una cognición jurisdiccional (por tanto, del procedimiento principal) está condicionada a la interposición de una querella; además, que el tribunal no puede actuar jamás de oficio, así un hecho punible se cometa en plena audiencia 'ante los ojos del tribunal', pues rige el axioma 'donde no hay acusador no hay juez'. Además, existe la obligación de perseguir y acusar y el tribunal tampoco puede extender un procedimiento, en el que él conoce, a otras personas o a otros hechos jurídicamente independientes del mismo autor. Añádase, que la interposición de la acusación le corresponde al Estado representado por la fiscalía que, en principio, tiene el monopolio de la acusación; incluso, se niega la sujeción de la fiscalía a la jurisprudencia del tribunal, lo que repercute también en la comprensión del principio acusatorio. Así las cosas, concluye, "de este modo, una condena presupone que dos autoridades -fiscalía y tribunal-consideran, de forma coincidente, que un comportamiento es punible, aun cuando no necesariamente en el mismo estadio del procedimiento" (2000, p. 86 y 87). Por supuesto, con semejante enfoque es entendible por qué el citado profesor afirma que el tipo de proceso penal que rige en un país, se constituye en el termómetro que indica el carácter autoritario o liberal de un Estado (2000, p. 10).

Desde el enfoque italiano pueden mencionarse múltiples y complejos estudios sobre el entendimiento del asunto, aunque aquí interesa destacar los de Petrone (1994) y Ferrajoli quien, con toda razón, lo llama como principio acusatorio o de la separación entre juez y acusación y que califica como el más importante de todos los elementos constitutivos del modelo teórico acusatorio (1995, p. 93, 561 y ss.).

Por su parte, desde la óptica hispana, Bujosa (2004) comulga con la división de funciones de acusación y juzgamiento, y entiende que la primera es el presupuesto de la segunda; afirma que es necesaria la distinción entre la investigación y la decisión, considerándose que la instrucción es preparatoria mientras que el fallo es el resultado de la actividad del juicio. Además, entiende que existe una clara sujeción de la decisión a lo pedido en la acusación y que, en consecuencia, se prohíbe la reforma en peor salvo que se trate de apelante plural. En fin, advierte que el juzgador debe asegurarse de mantener la objetividad y neutralidad necesarias al momento de emitir su decisión.

En una parecida dirección, el profesor Asencio Mellado, (1991) menciona como notas esenciales del postulado las siguientes: a) la 
existencia de acusación por órgano distinto al juez; b) La división de etapas de investigación y juzgamiento, con titulares diferentes, negándose la posibilidad de identidad entre investigador y juez; y, c) la vinculación de la decisión del juez a las pretensiones acusatorias, concibiendo la posibilidad de mutabilidad de la calificación jurídica de los hechos en pro del interés jurídico más no de los hechos (p.17). A su turno, Vicente Gimeno Sendra (1999), aúna a las ya descritas la prohibición de la reforma en peor (la reformatio in peius), en cuya virtud el juez no puede agravar la situación del acusado en la sentencia, salvo que no sea apelante único y está sometido en el trámite de la apelación a lo pedido en la impugnación (p. 78).

Desde otra perspectiva, Abad Liceras (2000) lo define como aquél que exige la acusación como antecedente del proceso y de la sentencia, la cual debe ser formulada por el Ministerio Público o fiscal o por un acusador particular (artículo 125.1 Constitución Española y el artículo 101 de la ley de Enjuiciamiento Criminal), quien ejercita la acción penal. Montero Aroca (1994), a su vez, estima que se caracteriza por la imparcialidad judicial, lo cual dota a sus intervinientes de la nota de supra partes de tal manera que el funcionario judicial está excluido del ejercicio de la investigación y de la acusación, so pena de afectar la imparcialidad que lo debe caracterizar (p. 537).

A su turno, para citar a uno de los más representativos exponentes de la doctrina hispana actual, Gómez, en su obra 'La investigación del crimen', asevera que el mencionado principio garantiza la imparcialidad y la neutralidad del juez respecto del objeto del proceso, esto es, el hecho criminal. Considera que la primera, supone la separación entre el órgano acusador y el juzgador, por lo cual no es posible condenar por hechos diferentes a los enunciados en la acusación, ni a persona distinta de la acusada; y, la segunda, obliga al operador a mantener la pasividad probatoria (p. 74). Este planteo -que recoge los desarrollos de su Maestro- asevera que el principio tiene tres aristas: a) Sin acusación no hay proceso y la misma debe ser formulada por persona diferente al juez; b) no puede proferirse condena por hechos ni en relación con persona distinta a la señalada en la acusación; y, c) el juez no tiene facultades de dirección material del proceso so pena de empañar su imparcialidad (Montero, p. 538). En fin, debe decirse que de forma precisa este gran teórico español sostiene que el postulado desarrollado por el sistema penal europeo se caracteriza por: a) requisito de acusación para que haya proceso, por persona distinta de quien juzga, es decir separación de 
funciones de acusación y juzgamiento; b) el fallo está limitado a los hechos de la acusación y a la persona acusada; y, c) el juez carece de facultad oficiosa de dirección material del proceso (Gómez, 2003, p. 41-46).

Vergé, a su vez, estima que los elementos del apotegma acusatorio son incoación de parte; existencia de acusador como requisito de validez del juicio -aunque presentada la acusación el juez no está vinculado con ésta-; incompatibilidad entre quien acusa y quien juzga; y, por supuesto, supone la actividad probatoria de parte, pues la imparcialidad debe caracterizar al denominado juzgador supra partes (1994, p. 21 y 22).

De la Oliva (1999), al hacer un muy buen planteo sobre el asunto, considera que un proceso en el que se respete el principio acusatorio es aquel en el cual se requiere de la acusación a uno o varios sujetos determinados por hechos concretos, como presupuesto del juicio oral que terminará con una decisión de condena (p. 42 y 43). Así mismo, para González, el principio se entiende desde dos puntos de vista. Uno positivo, caracterizado por la separación de las conocidas funciones, la correlación ente la acusación y el fallo y la vinculación del órgano jurisdiccional al objeto del proceso, evidente iniciativa probatoria del órgano jurisdiccional y la prohibición de la reforma en peor (2004, p. 23), y, desde la óptica negativa, en el principio acusatorio no es característica la separación entre quien instruye y quien juzga y el derecho de defensa (González, 2001, p. 144 y ss.; González, 2004, p. 159). A su vez, Ortego, cree que el principio acusatorio requiere de una parte acusadora pública o privada que ejerza la acción penal ante el juez, en un juicio que lo vincula al objeto del proceso, pudiendo condenar sólo por los hechos de la acusación y exclusivamente a la persona acusada ( p. 56 ).

En fin, también desde la perspectiva hispana, Díaz (1996) señala que el principio en estudio se traduce en la distinción de las funciones acusatorias y las decisorias y la adversariedad de partes, separando el apotegma acusatorio del dispositivo (p. 209, 214).

Así las cosas, debe decirse que España ha tenido una gran tradición en materia del principio acusatorio: primero, con la doctrina preconstitucional, en cuya virtud se sostenía que él encarnaba todo aquello que se edificase en contraposición a las normas inquisitivas, por lo cual implicaba los derechos de audiencia, de 
contradicción y de defensa, tal como lo manifestó en su momento Alonso Martínez, Padre de la antigua Ley de Enjuiciamiento Criminal todavía vigente. No obstante, otros lo relacionaban con la etapa de juicio de manera radical y atenuada en la investigación, admitiendo la participación de juez durante la investigación, situación que se mantiene en el proceso penal español actual (Guerrero, 2009, p. 62).

En la doctrina argentina Julio B. Maier expresa que:

La característica fundamental del enjuiciamiento acusatorio reside en la división de los poderes que se ejercen en el proceso, por un lado el acusador, quien persigue penalmente y ejerce el poder requirente, por el otro el imputado, quien puede resistir la imputación, ejerciendo el derecho de defenderse, $y$, finalmente, el tribunal, que tiene en sus manos el poder de decidir (1998, p. 207).

No muy distantes son los planteos de Bovino (2005) cuando considera que el axioma acusatorio se caracteriza por la distinción entre las funciones de persecución y juzgamiento (p. 37), con lo cual se logra la realización efectiva de una garantía fundamental, que denomina 'meta garantía' (1998, p. 10). Así mismo, a partir del enfoque chileno, dice Rodríguez (2013):

No es más que uno de los principios configuradores del proceso acusatorio que regula aspectos bien específicos de éste, cuyo contenido se ciñe a la separación de la función de acusación de la de enjuiciamiento, funciones que deben ser atribuidas a órganos distintos, y por tal motivo la acusación -el objeto del proceso- ha de ser planteada en juicio por un sujeto distinto del juez (p. 647).

Para Herrera (2005), acorde con la visión panameña del asunto, el acusatorio comporta la carga de la prueba en cabeza del Estado todo ello en el seno de un juicio oral, público y contradictorio entre partes investidas de los derechos propios de quien concurre a la actuación de la mano del postulado de la igualdad de armas.

Burgos, desde la legislación peruana, advierte que el principio acusatorio se determina por varias notas: la separación de funciones de investigación y juzgamiento; el juez no interviene en el proceso de oficio y le está prohibido condenar a persona distinta o por hechos diferentes de los imputados. Además, para que este postulado rija de verdad, asevera que en el proceso se deben observar los principios de oralidad, contradicción e igualdad, y debe primar la liber- 
tad del acusado durante su desarrollo (2005, p. 44). No muy lejos aparecen los planteos de Arbulú Martínez (2006), quien encamina la definición sobre el asunto para afirmar que el axioma es aquel en virtud del cual el Ministerio Público (acusador) persigue el delito, dejando en manos del juez el sentido del fallo, siendo la primera, la acusación, condición inexorable de la decisión.

Por supuesto, debe tenerse en cuenta que a través del Tribunal Constitucional, se identifica el principio acusatorio a partir de la separación de roles entre el Ministerio Público (fiscal) y el poder judicial (juez), siendo el primero el titular de la acción penal, cuya función es investigar y acusar; y, el juez, el responsable de juzgar y decidir sobre la culpabilidad o no del procesado, escenario en el cual la acusación es un requisito ineludible del juicio (Perú, Tribunal Constitucional, Caso Manuel Sandoval, 2006). Por ello, de forma puntual en cuanto a la resolución de sobreseimiento (conocida en Colombia como preclusión de la investigación) señala que si el Ministerio Fiscal como titular de la acción penal como dispone el artículo 159, de la Constitución política de Perú, decide retirar la acusación, el juez no puede iniciarla por su cuenta. (Perú, Tribunal Constitucional, Caso de la Defensoría del pueblo, 2004).

Además, el Tribunal ha señalado que el principio en estudio se caracteriza porque debe existir acusación como requisito anterior del juicio, la cual debe ser formulada por persona diferente al juzgador -en este punto se acepta la acción particular ejercida por persona diferente al fiscal- en la que debe predicarse la congruencia entre el facto narrado en la acusación y los hechos que sustentan la decisión, contra persona determinada y sin que, en ningún momento, el juez pueda dirigir materialmente el juicio, so pena de afectar su inexcusable imparcialidad (Perú, Tribunal Constitucional, Caso Ricardo Gómez, 2005).

En el ámbito mexicano, Meza (2009) señala que el principio acusatorio inscrito en el juicio oral determina la separación de las funciones de acusación y juzgamiento, bajo el presupuesto de una imparcialidad frente a las partes y a los hechos y en cuanto a las pruebas del proceso; supone la obligación de ejercer la acción penal por parte del acusador y su limitación para renunciar a la misma (p. 199).

Además, en el contexto hondureño deben mencionarse los aportes de Cuéllar (2002) quien, al coincidir con algunos de los expo- 
sitores hispanos ya citados, hace un intento por señalar las características del principio acusatorio que no distan mucho de las ya expuestas.

En Colombia, diversos estudiosos se ocupan del tema: por ejemplo, Guerrero enruta sus elaboraciones en la dirección ya apuntada de Gómez (2005, p. 81-86); y Bernal-Montealegre (2013), estiman que este axioma es propio del sistema vigente y comporta siete consecuencias distintas: a) las atribuciones de instrucción y juzgamiento están encargadas a dos órganos distintos; b) la decisión de responsabilidad penal debe establecerse a instancias de un órgano acusador; c) debe existir correlación entre la acusación y el fallo; d) opera de acuerdo con la ley el principio de reformatio in pejus; e) la investigación constituye una actividad que prepara el juicio oral y suministra el material necesario para que opere la contradicción; f) el proceso penal es una actividad en cabeza del Estado gobernado por el principio de legalidad de la actuación y de la prueba; y vii) las formas rituales que deben observar el procedimiento son la oralidad y la publicidad (p. 197).

Así las cosas, con la puesta en vigencia del nuevo Código de Procedimiento Penal se ha buscado adecuar un proceso con la mayor atención a los principios constitutivos del sistema penal acusatorio, en virtud del cual la jurisdicción la ejercen los tribunales populares, el ejercicio de la acción penal es pública y sólo se emplea a través de un proceso; la defensa y acusado están en igualdad de armas frente al ente acusador, la función del juez es exclusiva, restringida y nula en cuanto a la intervención oficiosa probatoria. Además, la regla general es la libertad del procesado durante el proceso; el procedimiento es oral, concentrado y público; y, por supuesto, se propende por la separación entre las funciones de acusación y de juzgamiento, algo propio del principio acusatorio.

\section{El sistema procesal penal colombiano.}

- Antecedentes.

Con la Carta Política de 1991, se adoptó un sistema procesal penal mixto con tendencia inquisitiva, el cual fue incorporado en el Decreto 2700 de 1991 y en la Ley 600 de 2000. Luego, ante la deficiencia del sistema, se acogió el diseño procesal acusatorio vertido en el ordenamiento jurídico mediante el Acto Legislativo 
03 de 2002 y el Código de Procedimiento Penal (Ley 906 de 2004) ${ }^{1}$ que entra a desarrollar la estructura del sistema penal de corte acusatorio, de tal manera que el principio acusatorio (objeto de estudio) es considerado como el elemento estructural del mismo ${ }^{2}$.

Dentro de la exposición de motivos del Proyecto de Acto Legislativo 237 de 2002, Cámara que, finalmente, se convirtió en el número 03 de 2002, que modificó de manera sustancial el artículo 250 de la Constitución Política, se pretendió abordar desde diferentes aristas el significado del sistema acusatorio: por ello, después de aceptar la deficiencia del sistema mixto vigente y de las necesidades de lograr cambios, se adoptó uno de tendencia acusatoria, en cuya virtud se predica la adversariedad entre contendores, acusador y defensa, en un plano de igualdad de armas en el que, como resultado del debate probatorio, un tercero imparcial tomará una decisión. En consecuencia, el juicio constituye la base del modelo, en el que las partes protagonizan la práctica de pruebas en presencia del juez, las cuales son sustento de la sentencia que emite, asegurando con ello su imparcialidad. Allí se lee:

La premisa anterior se sustenta en que, mientras el centro de gravedad del sistema inquisitivo es la investigación, el centro de gravedad del sistema acusatorio es el juicio público, oral, contradictorio y concentrado. Así pues, la falta de actividad probatoria que hoy en día caracteriza la instrucción adelantada por la fiscalía, daría un viraje radical, pues el juicio sería el escenario apropiado para desarrollar el debate probatorio entre la fiscalía y la acusación. Esto permitirá que el proceso penal se conciba como la contienda entre dos sujetos procesales: defensa y acusador, ubicadas en un mismo plano de igualdad, al final del cual, como resultado del debate oral y dinámico, el tercero imparcial que es el juez, tomará una decisión. (Cámara de Representantes, Exposición de motivos al Proyecto de Acto Legislativo 237, 2002).

Así las cosas, el cambio propuesto respondía a la necesidad de una transformación de fondo tras advertir las deficiencias del modelo implantado con anterioridad; no obstante, tras diez años de puesta en vigencia de ese sistema se puede advertir hoy que por la vía de las construcciones jurisprudenciales una práctica judicial incoherente ha terminado por mezclar el modelo novedoso entonces adoptado con su predecesor, deformando así la aplicación debida del principio acusatorio y, por ende, del sistema lo cual ha significado un retroceso en el avance del proceso penal en el país. 
- El principio acusatorio en la jurisprudencia.

La Corte Constitucional, como órgano supremo y guardián de la Carta Política, ha sido enfática en señalar que el sistema penal de tendencia acusatoria obedeció a las necesidades y particularidades propias del país, admitiendo que su concepción no es pura y que, por el contrario, se trata de un sistema de partes modulado por un proceso adversarial, dejando ver entre frases que el modelo Colombiano rescata del puro algunos elementos tales como la igualdad de armas entre las partes, con un procedimiento oral, público y contradictorio, sin embargo aceptó que fue acondicionado a las particularidades del país (Corte Constitucional, sentencias C-873, 2003; C-591, 2005; C-1194, 2005; C-454, 2006; C-209, 2007; C-396, 2007; C-186, 2008; C-025, 2009; C-069, 2009; y C-144, 2010, entre otras).

En igual sentido, al trazar el modelo, la alta Corporación señaló que desde el punto de vista teleológico y sistemático del ya citado Acto Legislativo de 2002 y lo normado en desarrollo del mismo, se caracteriza por la separación de las etapas de instrucción y causa, siendo la primera el espacio para la preparación del juicio $y$, la segunda, el momento en el cual se concibe al juez como aquel que ejerce el control jurisdiccional de los actos que ocasionen la limitación de los derechos fundamentales, por lo cual su función no es oficiosa sino a petición de parte. En consecuencia el proceso penal es oral, contradictorio, público y concentrado y se permite la aplicación del principio de oportunidad en los casos previstos bajo causales precisas, existe distinción entre las potestades de los jueces de control de garantías -quienes tiene como función la de proteger las garantías individuales y derechos en las etapas preliminares a la imputación -y las de los jueces de conocimiento- a los que les corresponde adelantar el juicio con el respeto de las garantías procesales (Cfr. Corte Constitucional, Sentencia C-396, 2007). Es más, dicho organismo coincide con la doctrina especializada al indicar que el principio acusatorio, denominado nemo iudex sine actore, se caracteriza por la separación de funciones entre el acusador y el juez (Cfr. Corte Constitucional, Sentencia C-818, 2005).

Por su parte, la Sala de Casación Penal de la Corte Suprema de Justicia ha bautizado el sistema -no el principio, que es cosa distintacomo adversarial cuando señala que Colombia no acogió un sistema acusatorio puro sino que, por el contrario, el Constituyente adecuó uno para satisfacer sus necesidades y posibilidades. Así, afirmó que el principio llamado adversarial no era absoluto, pues la estructura 
desarrollada en Colombia permitía matizar sus componentes, aceptando la intervención activa de la víctima y del Ministerio Público en el juicio, figuras que dentro del esquema de los sistemas penales acusatorios puros no tienen participación alguna (Sentencia 30 de marzo, 2006). De igual forma, asevera que el juez no ocupa un papel pasivo frente a los contendores -como bien se aprecia en un sistema acusatorio primigenio- puesto que en aras de emitir un fallo basado en la verdad real y en la justicia material, debe tener una actitud pro activa encaminada a proteger los derechos fundamentales de los actores de amenazas o vulneraciones.

Por ello asevera que la reforma del artículo 250 constitucional, le encomendó a la Fiscalía la función -no judicial- de presentar la acusación ante el juez de conocimiento de cara a iniciar con ello el juicio oral, público, concentrado y respetuoso de garantías procesales. Además, se advierte que el Acto Legislativo trajo consigo características propias pero disimiles a las del modelo desarrollado por otros países, y destaca como axiomas la igualdad de armas en el juicio entre la fiscalía y la defensa, la iniciativa probatoria de la fiscalía para la demostración de su estrategia, la separación entre los actos de investigación, acusación y juzgamiento, que son exclusivas de ella y del juez.

Sin embargo, en cuanto a la imparcialidad del juez respecta, estima que si bien en el artículo 361 del Código de Procedimiento Penal se establece que el operador no puede decretar pruebas de oficio, existe la posibilidad constitucional excepcional de hacerlo; por ello, cree viable que el juez razonadamente y en el caso concreto pueda motivar la inaplicación del artículo 361 del citado estatuto procesal, so pretexto de dar prelación a los mandatos, principios y fines constitucionales del proceso penal, soportados en el artículo $4^{\circ}$ de la Constitución, por ser el punto de inicio y cierre del ordenamiento jurídico.

No obstante, la Corte Constitucional señaló que en su criterio el juez de control de garantías o de conocimiento no puede ser un mero árbitro frente a las partes y que, por el contrario, debe propender por la búsqueda de la verdad y la justicia material, salvaguardar los derechos fundamentales y las garantías del acusado y los derechos constitucionales de las víctimas (Cfr. Sentencia C-591, 2005). Incluso luego, zanjó la discusión en relación con la potestad probatoria del juez (como punto minado de su imparcialidad y de su neutralidad), concluyendo que en tratándose de un juez de control de garantías 
dicha prohibición es relativa, con el argumento de que se busca proteger los derechos fundamentales objeto de control; sin embargo, frente al juez de conocimiento dijo que esa potestad es absoluta al ostentar una función de dirección del debate probatorio, lo cual le impide desquiciar el modelo de matiz acusatorio y transgredir tanto su objetividad como el axioma de la igualdad de partes, características del principio adversarial y del sistema penal acusatorio, según dijo. (Cfr. Corte Constitucional, Sentencia C-396, 2007).

\section{La realidad del principio acusatorio en Colombia.}

Si bien, el principio acusatorio concebido en Colombia tiene ciertas modificaciones que el constituyente visionó como necesarias para su adecuación al modelo acusatorio (o de tendencia acusatoria) introducido, debe estudiarse si los desarrollos observados se corresponden con la esencia de aquel o si, por el contrario, desquician su naturaleza, de tal manera que se pueda concluir si realmente tiene aplicación en el proceso penal. Ese, pues, es el objeto del presente apartado.

Así las cosas, si se tienen en mente las diversas notas que la doctrina le atribuye al principio ya vistas, se advierte que el postulado aplicado en el país posee características que no se corresponden con aquellas. Ejemplos claros de lo afirmado son el papel de la víctima en el juicio como interviniente especial; la interferencia del Ministerio Público como interviniente principal y discreto; $y$, añádase, la neutralidad probatoria relativa del juez, sobre los cuales se quiere discurrir a continuación. Su incorporación a la estructura del proceso vigente es producto de la clasificación que hace el Código de los actores en partes e intervinientes (artículos 113 y ss.), donde incluye como partes a la fiscalía y a la defensa (amén del imputado y acusado, como unidad), y como intervinientes al Ministerio Publico, a la víctima; el Juez, adviértase, es el Director de la actuación judicial y también participa el tercero incidental (Cfr. Corte Constitucional, Sentencia C-873, 2003).

Desde luego, las atribuciones otorgadas a esos actores son diversas y no existe controversia en relación con las que les corresponden a las partes (fiscalía y defensa), toda vez que tanto la Constitución como el estatuto procesal penal establecieron que el proceso ventilado dentro del sistema con tendencia acusatoria es protagonizado por ellas que, además, son consideradas como contendoras en el escenario judicial. 
Sin embargo, no puede predicarse igual situación en relación con la participación activa del Ministerio Público y la víctima, rotulados como intervinientes, puesto que la discusión no ha sido pacífica. La Corte Constitucional los denomina como actor principal y discreto y especial, en su orden, admitiendo su extraña ubicación dentro del proceso penal (en comparación con el modelo acusatorio implantado en otros países, de corte anglosajón, como por ejemplo el estadounidense), o por lo menos disímil (de acuerdo a la exposición de los autores en el respectivo capítulo), pero no por ello carente de importancia (Corte Constitucional, Sentencia C-260, 2011).

Por ello, la propia Corte Constitucional señala -al examinar el papel del juez en la búsqueda de la materialización de la justicia material y como guardián del respeto de los derechos fundamentales y de las garantías de los actores del proceso, amén de la participación del Ministerio Público y de la víctima- que el proceso adoptado no es adversarial puro (Cfr. Sentencia C-591, 2005). De igual manera, en cuanto a las potestades y facultades de estos intervinientes principal y especial, esa Corporación reitera que el proceso penal tiene características -como la participación del Ministerio Público en defensa de la legalidad y el respeto de los derechos humanos y la víctima en defensa de sus propios derechos- que le imprimen identidad única en relación con otros sistemas procesales ${ }^{3}$.

Así las cosas, es por la actividad del juez y la participación activa de los intervinientes que la jurisprudencia constitucional estima que el proceso penal es de partes, adversarial, por lo cual en un sistema modulado de tendencia acusatoria no puede hablarse de un sistema penal acusatorio propiamente dicho $\mathrm{y}$, mucho menos, de la existencia de un auténtico principio acusatorio. Y no es para menos: las atribuciones de los intervinientes en el proceso penal vigente desquician ese apotegma y la estructura del adversarial, por lo cual es necesario analizar de manera minuciosa sus alcances dentro de la investigación y el juzgamiento, para entender de mejor manera la afirmación acabada de hacer. A esa tarea se destinan las siguientes líneas.

\section{La víctima, interviniente en el proceso penal colombiano.}

La víctima, que puede ser sujeto pasivo de la conducta punible, y/o aquel perjudicado con ocasión del injusto, es un interviniente en la estructura del proceso penal actual que ha adquirido una importancia extrema, la misma que ya empezó durante la vigencia de la Ley 600 de 2000 -que, recuérdese, todavía se aplica para ciertos 
sujetos de la ley penal, para el caso aforados- sobre todo a raíz de algunos pronunciamientos de la jurisprudencia.

Como se recordará, el artículo 250 original de la Constitución Política de 1991 -norma de normas, punto de inicio y finiquito del ordenamiento jurídico- establecía la obligación de la fiscalía de propender por la protección de la víctima ya desde el momento en el que tuviera conocimiento de la realización de la conducta y le imponía el deber de adoptar las acciones tendentes a lograr el restablecimiento de sus derechos y el pago de los perjuicios con ocasión del injusto. Ese precepto constitucional fue desarrollado en su momento por el anterior y derogado Código de Procedimiento Penal, para el cual la víctima era concebida como un verdadero sujeto procesal siempre y cuando actuara a través de apoderado y se constituyera como parte civil, con la pretensión de obtener el resarcimiento de los perjuicios individuales y colectivos causados con el delito, como se disponía en su artículo 45 (Congreso de la República, Ley 600, 2000). Además, a la fiscalía como director de la instrucción le correspondía proteger a las víctimas, cosa que también sucedía con los testigos y otros intervinientes incidentales en el proceso, y debía adoptar las medidas necesarias tendentes al resarcimiento de los perjuicios y el restablecimiento del derecho, si a ello hubiere lugar, como se infería del artículo 114 de esa normatividad.

Por ello, la víctima actuando como parte civil, contaba con una participación activa en el proceso, podía solicitar la práctica de pruebas, tanto en la instrucción como en la causa, recurrir las decisiones, participar activamente en el ritual probatorio (Congreso de la República, Ley 600, 2000, art. 407) y presentar alegatos previos al fallo (Congreso de la República, Ley 600, 2000, art. 393 inciso $2^{\circ}$ ). Tenía pues, una vez constituida como parte civil, iguales facultades que los demás sujetos procesales. Ello era producto del modelo de corte mixto de tendencia inquisitiva que se implantó entonces en Colombia; sin embargo, no se puede decir que el sistema aplicado hasta el año 2004 -con la salvedad ya anota en lo que toca con su vigencia- fuera insuficiente -basta con aceptar su deficiencia- de lo que se trata es de advertir que la criminalidad y la impunidad se mostraron incontrolables y el sistema se tornó inane para abarcar tal problemática estructural que, en términos de justicia, terminó por desajustar y tornar inoperante el patrón adoptado.

Con posterioridad, el ya citado Acto legislativo 03 de 2002 adoptó el nuevo modelo de contenido acusatorio o mejor llamado 
por la jurisprudencia y doctrina adversarial, como se ha dicho ya, en virtud del cual se le encomendaron a la Fiscalía General de la Nación las funciones de investigación y acusación, por lo cual se le despojó de la potestad de precluir las investigaciones adelantadas que tenía hasta ese momento. En consecuencia, la función de juzgar se dejó en cabeza del juez concebido como un ente imparcial dentro de la contienda de partes, dotado de ojos para ver y de oídos para oír, pero sin manos para actuar; todo ello, porque acorde con el diseño acogido él se debe limitar a acoger una de las teorías del caso propuestas en el juicio sin la facultad de decretar pruebas de oficio que puedan desequilibrar el esquema, supeditando su fallo al desarrollo del debate probatorio de las partes (Congreso de la República, Ley 906, 2004, art. 361).

Pero la fiscalía, según ya se dijo, conservó la potestad de proteger a la víctima y de satisfacer sus necesidades al interior del proceso (Congreso de la República, Ley 906, 2004, art. 114), además las de la ejecución de las medidas encaminadas a su atención y protección inmediata, la comunicación e información, etc. funciones señaladas en la ley 906 de 2004, Título IV (art. 132). Así las cosas, la víctima aparece como un interviniente, pero se le otorgaron una serie de atribuciones o facultades para actuar por sí misma, so pretexto de la verdad, la justicia y la reparación integral, que son fines del proceso penal (véase Congreso de la República, Ley 906, 2004, art. 137); no obstante, a partir de la audiencia preparatoria se le exige que actúe a través de un profesional del Derecho, aunque cuando carece de recursos la fiscalía lo debe proporcionar de oficio. Por supuesto, con ello comenzó a cojear todo el sistema adoptado si se tiene en cuenta que, en modelos como el vigente en los Estados Unidos de América, no se le da cabida a la víctima en la actuación (Gómez \& Esparza, 2013, p. 169-180).

Añádase que, en principio, el estatuto procesal penal establecía que la víctima, además de ser asistida y protegida por la fiscalía, tenía la facultad de intervenir en las actuaciones y diligencias por intermedio de ésta y, en apariencia, le era prohibido elevar solicitudes encaminadas a la práctica de pruebas e intervenir de forma activa en la consecución de las decretadas por el juez, en el entendido de que dichas atribuciones terminarían por desequilibrar el proceso de partes. Es más, como posible sujeto pasivo del delito, se le otorgó a la víctima el derecho al resarcimiento de los perjuicios ocasionados con ocasión de aquel, así como también a hallar la verdad y la justicia. 
Sin embargo, en aplicación del control constitucional, la Corte Constitucional, se ocupó de la revisión del articulado atinente a la víctima y emitió sendos pronunciamientos en los que todo cambio, $\mathrm{y}$, de las buenas intenciones encaminadas a tener un modelo de partes adversarial, de garantía en garantía, se terminó por establecer su participación en la actuación que hoy solo puede ser calificada poco menos que de "absoluta" (Cfr. Corte Constitucional, Sentencia C-209, 2007). Por eso, dijo que la víctima era un interviniente especial que tiene intereses concretos en el proceso, como lo son el derecho a la verdad (en el entendido que se logre que la procesal sea la verdad material), a la justicia (garantizando el derecho a evitar la impunidad) y a la reparación integral (el cual se refiere a la forma tradicional de pago económico), razón más que suficiente para permitirle actuar activamente en el proceso más allá de un simple convidado de piedra, aunque se advierte que ello se plantea sin que resulte contraviniendo el sistema adversarial. Además, se dijo que ella debe ser tratada con dignidad y que tiene todo el derecho a conocer las decisiones que la afectan y a la tutela judicial efectiva, como forma de acceder a los susodichos fines (verdad, justicia y reparación integral) (Véase, Corte Constitucional. Sentencia C-228, 2002; Sentencia C-454, 2006).

Es más, se citaron sus derechos desde la óptica internacional, consagrados en los artículos 8 y 25 de la Convención Americana de Derechos Humanos que contemplan el derecho a la tutela judicial efectiva (normas concordantes con el ordenamiento interno: artículos 29 y 229 de la Constitución Política), en especial el último de los citados que establece la posibilidad de que las víctimas puedan intervenir en los procesos, gozar de atención y garantías y ser indemnizadas cuando sufran perjuicios (Organización de los Estados Americanos, Pacto San José de Costa Rica, 1969). Incluso, la Corte señala que el derecho a la tutela judicial efectiva se traduce en el derecho de acceso a la administración de justicia, como el mecanismo idóneo para lograr la verdad, la justicia, el restablecimiento del derecho, la indemnización de los perjuicios, a recibir información, a obtener decisiones de fondo, a participar en el proceso, incluso desde la indagación preliminar y a ser escuchada, todo dentro de una concepción amplia de sus derechos (Cfr. Corte Constitucional, Sentencia C-454, 2006).

De esta manera, se entiende que la víctima tiene derecho a la tutela judicial efectiva como forma de lograr la verdad, la justicia 
y la reparación integral en los términos ya señalados; sin embargo, esa protección se materializa desde el inicio de la investigación, al poner en marcha el andamiaje jurisdiccional a fin de sancionar a los responsables de la conducta punible que le ocasionaron perjuicios de cualquier índole. Incluso, se recuerda que la participación de la víctima en el proceso penal -contemplada en Acto Legislativo 03 de 2002-, debe ser objeto de reglamentación legal para considerarla en atención a su condición e intereses en el proceso, en el entendido de que su participación no se circunscribe solo al aspecto económico, por lo que debe ser considerado como un sujeto especial, sin importar la denominación de parte o interviniente que se le dé; además, para prever la figura de acuerdo a los rasgos y características del sistema que se considera adversarial (de partes) modulado, con tendencia acusatoria (Cfr. Corte Constitucional, Sentencia C-454, 2006).

Es en este punto en el que se considera que si bien el Acto Legislativo guardó prudencia, la ley y la jurisprudencia (esta última de manera dañina) dieron rienda suelta al otorgamiento de potestades al interviniente especial, tirando por la borda la estructura propia del sistema. Por supuesto, no se pretende con lo dicho dejar sin medios idóneos a la víctima para materializar sus fines, pues está claro que la Constitución le permite a cualquier persona hacer efectivo su derecho a la tutela judicial efectiva (1991, art. 229) y le endilga a la fiscalía claras y precisas obligaciones. No se trata, pues, de considerarla como desvalida; por el contrario, es evidente que mucho antes de que la jurisprudencia -en un derroche de garantías- le permitiera acomodarse activamente en el juicio, la Constitución la dotó de herramientas, unas a cargo de ella y otras dependientes de la fiscalía, todas encaminadas a materializar sus derechos en el proceso.

Sin embargo, a lo largo de los últimos años la Corte ha modulado su participación en el proceso a través de sentencias, como la que declaró la exequibilidad del numeral 4 del artículo 192 del Estatuto Procesal, para permitir que ella pueda recurrir el fallo absolutorio (Cfr. Corte Constitucional, Sentencia C-979, 2005). También, ese organismo se ocupó del derecho a la información a las víctimas por parte de los órganos de investigación desde el momento en que tengan comunicación con las autoridades (Corte Constitucional, Sentencia C-1154, 2005). Incluso, se declaró exequible el artículo 79 del Código incluyendo el requisito de motivación de la decisión de archivo y que la misma fuera comunicada al denunciante y al 
Ministerio Publico (Corte Constitucional, Sentencia C-1154, 2005); además, con similar condición, se declaró la exequibilidad del artículo 69 en relación con la inadmisión de la denuncia (Corte Constitucional, Sentencia C-1177, 2005).

El pronunciamiento de constitucionalidad declaró la exequibilidad del artículo 135 del Estatuto Procedimental -que se ocupa de la garantía de comunicación a las víctimas, concretamente para solicitar su pretensión económica-, en el entendido de que debe hacerse desde el momento del contacto con las autoridades y la misma no sólo debe garantizar la reparación integral sino, además, los derechos a la verdad y a la justicia (Cfr. Corte Constitucional, Sentencia C-454, 2006). Mediante esa decisión fue declarada exequible la facultad de la víctima para elevar solicitudes probatorias, potestad establecida en el artículo 357 del estatuto procedimental.

También, se declaró inexequible el artículo 327 que le negaba a la víctima la posibilidad de recurrir la decisión que aprueba la aplicación del principio de oportunidad (Corte Constitucional, Sentencia C-209, 2007).

De igual manera, con la finalidad de hacer extensivos sus derechos, la Corte declaró la constitucionalidad condicionada de algunos apartes legales y facultó a la víctima para: solicitar la práctica de pruebas anticipadas; asistir a la audiencia de imputación; allegar o solicitar elementos materiales o evidencia física para oponerse a la solicitud de preclusión; solicitar el descubrimiento de un elemento material probatorio o evidencia física específicos; hacer observaciones sobre el descubrimiento de los mismos y de las pruebas que se harán valer en juicio; y solicitar la exhibición de los elementos materiales de las pruebas durante la audiencia preparatoria. Así mismo, solicitar la exclusión, el rechazo o la inadmisibilidad de los medios de prueba en la audiencia preparatoria; acudir ante el juez competente para solicitar medida de aseguramiento o medidas de protección; y efectuar observaciones al escrito de acusación o manifestarse sobre posibles causales de incompetencia, recusaciones, impedimentos o nulidades (Corte Constitucional, Sentencia C-454, 2006).

Con similar finalidad, declaró inexequibles el ordinal $\mathrm{h}$ del artículo 11 y el numeral 4 del artículo 137 ibídem, por limitar el derecho de postulación en el caso de existir más de una víctima, por considerarse desproporcionadas tales limitantes en desmedro 
de sus derechos (Corte Constitucional, Sentencia C-516, 2007). También, ordenó excluir del ordenamiento la palabra "directa" de los incisos primero y segundo del artículo 92; "directo" del artículo 132; el inciso segundo del artículo 102; y el numeral $4^{\circ}$ del artículo 137, por limitar el concepto de víctima. De igual manera, declaró la constitucionalidad condicionada de los artículos 348, 350, 351 y 352 de la ley 906 de 2004, facultando a la víctima para que intervenga en los acuerdos y preacuerdos (Corte Constitucional, Sentencia C-454, 2006); además, hizo otro tanto con el art. 101, en el entendido de que también la víctima tiene la facultad de solicitar la suspensión provisional del poder dispositivo sobre bienes sujetos a registro (Corte Constitucional, Sentencia C-839, 2009).

Lo anterior confirma, pues, la tarea de la Corte encaminada a colmar a la víctima de garantías procesales que le permitan materializar sus derechos; sin embargo, ha señalado que su intervención directa en las instancias procesales puede en algún momento menoscabar los rasgos estructurales del sistema adversarial, llegando a anular principios como el de la igualdad de armas; de tal manera que es necesario establecer en qué eventos no pueden ser extensivas a las víctimas las facultades de otras partes, pues con ello podría descomponer y desnaturalizar el modelo. Por eso sostiene, en concreto, que en la etapa del juicio -donde se predica la atención extrema del principio de igualdad de oportunidades-, instancia en la que las partes, fiscalía y defensa, son los llamados a protagonizar la intervención de las víctimas, puede llegar a truncar la materialización de la adversariedad o la tendencia acusatoria.

Advirtiendo la Corte la posible mutación del sistema en cuanto a su participación en la práctica de pruebas (por ser este un punto dirimido por la Constitución y la ley) concluyó que su limitación estaba justificada en lo adversarial del sistema (Cfr. Corte Constitucional, Sentencia C-209, 2007). Sin embargo, agregó que en las demás etapas del proceso tenía la posibilidad de impulsar el procedimiento sin sustituir las funciones de la fiscalía; por tanto se concluye que su participación en el juicio se limita en atención al carácter adversarial, pero en las demás etapas procesales, indagación, investigación y acusación por no haber sido definidas por el legislador como adversariales, se admite que el papel sea más activo. Por supuesto, con tales decisiones la Corte terminó por sepultar el principio acusatorio, porque si algo está claro es que este no se predica sólo del juicio sino de todo el proceso; además, su aplicación debe ser constante y no intermitente. 
Peor aún, como se verá más adelante, ni siquiera en el juicio se respeta el principio acusatorio, al permitirse al Ministerio Público ejercer el contrainterrogatorio y oponerse a las preguntas, dejando a un lado, el postulado de la igualdad de armas y la batalla de partes en la práctica de las pruebas (Cfr. Corte Constitucional, Sentencia C-209, 2007). No obstante, se consideró que la participación de la víctima de manera directa en el juicio oral tiraría al traste con el sistema penal, al convertirse en un segundo acusador que desequilibraría la balanza y con ello el modelo; entendió ese organismo que no hay violación de sus derechos en el juicio, en el entendido de que la fiscalía es la encargada de ser el vocero de las intervenciones y el apoderado también puede ejercer las facultades propias de su calidad, de tal manera que sus derechos no se vean limitados, por lo cual estimó que la comunicación debía ser fluida entre ellos y que esa situación debía ser verificada por el juez (Cfr. Corte Constitucional, Sentencia C-209, 2007).

Así las cosas, más que decantado el papel de la víctima en el proceso penal, es claro que ella goza de un protagonismo inusual, con ciertas limitaciones en el juicio, que realmente -contrario a lo manifestado por la Corte Constitucional- sí logran desquiciar el modelo de partes so pretexto de materializar sus derechos con la efectividad de la tutela judicial, lo cual como ya se dijo se lograba antes del reconocimiento de la cantidad de garantías anti-acusatorias con las que se adornó a un interviniente que ya contaba con la protección y la atención necesaria para lograr sus objetivos en el proceso.

Si se quiere, los órganos de la Fiscalía y del Ministerio Público, las garantías constitucionales y legales que implica el debido proceso, el principio de legalidad y los controles jurisdiccionales, se convierten en los verdaderos mecanismos de revisión y control sobre las facultades decisorias del ente acusador, por lo que su participación activa en el proceso penal, en atención al sistema adversarial -es decir, de partesno debería ir más allá del logro de un fin del proceso, para el caso la satisfacción de sus derechos. Sin embargo, permitir que sea la víctima quien actúe en la búsqueda de la reparación no deja de ser un contrasentido, pues es el Estado -quien detenta el poder punitivo acorde con los principios de necesidad y oficialidad- el llamado a administrar justicia y a proporcionarle a todas las partes y no solo a la víctima la verdad y la justicia.

Por ello, para recabar sobre un aspecto importante, permitirle a la víctima hacer peticiones probatorias en la audiencia preparato- 
ria es brindarle una potestad contraria al modelo acusatorio y, por tanto, al principio acusatorio, puesto que la sentencia debe ser resultado del debate probatorio aportado por las partes, la fiscalía y la defensa, y no el producto de la intervención de la víctima o de otros intervinientes. Incluso, mucho menos resulta atemperado el sistema cuando se le permite al apoderado de la víctima incluir en juicio su alegación, argumentando que se trata de una etapa final en la que se escucha la posición de la víctima, puesto que en el pensamiento del juez solo deben quedar las alegaciones de la defensa y la fiscalía, para finalmente proferir un fallo.

Se reitera, pues, que la víctima en el proceso es un interviniente por lo que el legislador atendiendo al modelo por el cual optó, de forma expresa limitó su participación en el juicio; por ello, en lo no regulado ni la ley ni la jurisprudencia pueden desnaturalizar lo acusatorio con el otorgamiento de facultades tales como las ya vista, con lo cual podría concluirse que con ello devolvieron el sistema al modelo inquisitivo propio de la Ley 600 de 2000.

\section{El Ministerio Público en el proceso penal colombiano.}

El órgano llamado en el derecho positivo como Ministerio Público no es un instituto propio del sistema penal acusatorio ni del principio acusatorio, por lo cual no se puede acudir al derecho comparado -donde no existe con esas características, o se utiliza esa denominación para designar a la fiscalía- para hacer una reflexión sobre su papel en la estructura del proceso adoptado; por ello, solo en el modelo colombiano se incluye este actor de manera activa y equilibrada, con facultades autónomas que le permiten defender el interés público y el orden jurídico. Su inclusión en el proceso penal, recuérdese, tiene precedentes en la Ley 600 de 2000 que lo considera un sujeto procesal con iguales facultades, además de las especiales, que la fiscalía, la defensa, el procesado y la víctima, entre otros.

No obstante, en la Ley 906 de 2004 se le incorpora al sistema y su papel-como el de la víctima- es considerado como una característica propia del, así denominado por la Corte Constitucional, sistema adversarial modulado con tendencia acusatoria (sentencias C-873, 2003; C-591, 2005; C-1194, 2005; C-454, 2006; C-209, 2007; C-396, 2007; C-186, 2008; C-025, 2009; C-069, 2009; y C-144, 2010, entre otras). Por supuesto, la finalidad de la intervención del Ministerio Público en el proceso no es otra que la defensa de orden jurídico, del 
patrimonio público, o de los derechos y garantías fundamentales; sin embargo, la figura suele en ocasiones desdibujarse en el escenario procesal puesto que la asunción de determinada posición termina por desconocer justamente los fines de su intervención.

Por ello, el organismo encargado de guarda e integridad de la Constitución entiende que las facultades del Ministerio Público en el proceso penal son una notoria particularidad del sistema penal implantado, por lo cual parece admisible -según ese punto de partida- aceptar que intervenga en todo el trámite procesal al tenor de lo señalado en el artículo 277 de la Constitución Política (Corte Constitucional, Sentencia C-591, 2005); incluso tiene facultades de iniciativa probatoria (excepcionalmente), de tal manera que, en caso de olvido de alguna de las partes en relación con pruebas de vital trascendencia para su teoría del caso, el Ministerio Publico las peticione.

De ahí que se destaque su papel como un interviniente principal y discreto, activo en todas las etapas del proceso, en cuya virtud debe velar por los intereses de la sociedad, el respeto de los derechos y garantías procesales y la legalidad, el equilibrio entre las partes para impedir el exceso o abuso de una sobre otra; desde luego, ello hace que sus actuaciones no desnaturalicen el sistema al mantenerse, pese a su injerencia, como un proceso de partes en el que fiscalía y defensa gozan de igualdad de oportunidades (Corte Constitucional, Sentencia C-144, 2010). Esto último, téngase en cuenta, es contrario a lo que se considera en tratándose de los intereses de la víctima que persigue la condena del procesado, tornándose en un segundo acusador.

No obstante, no es cierto que esa interferencia no se presente pues si se le permite participar de los contrainterrogatorios y de la oposición a las preguntas en una estructura en la que sólo las partes interrogan, contrainterrogan y se objetan, es evidente que ese interviniente termina por inclinar deliberadamente la balanza (Corte Constitucional, Sentencia C-209, 2007). De igual manera, debe decirse que su intervención en el proceso deviene innecesaria, puesto que si se pretende justificar su participación como guardián de la legalidad, de los intereses de la sociedad, de los derechos humanos y los derechos fundamentales, el juez -ya sea de control de garantías o de conocimiento- está obligado a respetarlos y a garantizarlos en virtud del principio de legalidad. De igual manera, los fines ya referidos están protegidos por el ejercicio de los fines del proceso que cobijan a todas las partes e intervinientes. 
Así mismo, es claro que la Fiscalía detenta la titularidad de la acción penal (Constitución Política, 1991, art. 250) y entre sus facultades está la investigación de los delitos. Sin embargo, tiene la potestad de archivar aquellas investigaciones que no constituyen ilicitud (Congreso de la República, Ley 906, 2004, art. 79) y tal decisión, a pesar de ser autónoma, debe ser notificada al Ministerio Público quien puede impugnarla en caso de que la considere contraria a la ley (Corte Constitucional, Sentencia C-144, 2010). De igual manera, a pesar de predicarse igualdad de oportunidades entre la fiscalía y la defensa, como contendores en el juicio, se admite desequilibrar la balanza al facultar al Ministerio Público para interrogar al testigo pero no se le permite contrainterrogar -porque no se quiere desequilibrar el sistema-; no obstante, cuando se le da la sola posibilidad de interrogar se desvirtúa el esquema adversarial puesto que, se reitera, su función no es otra que la de defender los intereses de la sociedad y las garantías en el proceso, de cara a mantener la igualdad de armas, la participación en una proporción justa y el principio acusatorio.

En fin, la función del Ministerio Público está superada e inmersa en el mismo proceso penal; sin embargo, permitirle -así sea de manera condicionada- su intervención en el juicio sí desequilibra el sistema y, por ende, desnaturaliza el principio acusatorio, puesto que la igualdad de armas cede frente a su pretensión, por ser un tercero ajeno a los contendores que participa en el juicio y que desequilibra la balanza, desquiciando el sistema adversarial.

\section{La neutralidad probatoria del juez.}

Otra de las formas de quebrantar la vigencia del principio acusatorio, es el desconocimiento de la neutralidad probatoria del juez, como ha sucedido con un sector de la jurisprudencia (la Sala de Casación Penal, mediante sentencia de 30 de marzo 2006, radicado: 24468, afirmó que el juez puede de oficio -ello a pesar de la prohibición legal expresa contenida en el artículo 361 del C. P. P.-, en casos excepcionales, decretar pruebas de oficio); por ello, es necesario ocuparse de esta materia. Al respecto, debe advertirse que en esta sede no se habla de imparcialidad judicial porque esa no es una característica del principio acusatorio; ese término, el de imparcialidad judicial, es utilizado por el artículo 10 de la Declaración Universal de los Derechos Humanos para señalar la garantía de toda persona a ser oída y juzgada por un juez natural, independiente e imparcial 
(Organización de las Naciones Unidas, Declaración Universal de los Derechos Humanos, 1948).

Por su parte, la previsión constitucional establece que quien ejerza las funciones de control de garantías en determinado asunto no podrá ejecutar las de conocimiento del caso como forma de imparcialidad judicial (1991, art. 250). Así las cosas, la imparcialidad jurisdiccional no debe ser concebida como una característica propia del modelo acusatorio como se dijo y, por ende, del principio, sino como un elemento esencial del proceso con independencia de cuál sea su naturaleza. No obstante, es importante dilucidar si se debe hablar de imparcialidad jurisdiccional o de neutralidad judicial, dos conceptos bien distintos.

De un lado, la imparcialidad jurisdiccional deviene de todo operador jurídico en todo proceso sin que importe su naturaleza y se traduce en la obligación de aquel de guardar una aptitud y actitud recta, ecuánime, equilibrada y justa en relación con su forma de administrar justicia, la cual debe ajustarse al principio de legalidad; por algo, pues, el Código de Procedimiento Penal (2004), reza de la siguiente manera: "Imparcialidad. En ejercicio de las funciones de control de garantías, preclusión y juzgamiento, los jueces se orientarán por el imperativo de establecer con objetividad la verdad y la justicia" (art. 5). Por ello, en caso de advertirse parcialidad jurisdiccional, el mismo ordenamiento jurídico contempla herramientas procesales que bien pueden diluirla, como sucede con los artículos referentes a las causales de impedimento y recusación las cuales persiguen el saneamiento del proceso en relación con la imparcialidad del juez una vez comprobada una de ellas, con la consecuencia procesal de que se separa al funcionario del conocimiento el asunto, como lo disponen los artículos 56 a 60 del Código de Procedimiento (Cfr. Corte Constitucional, Sentencia C-881, 2011). Esta forma de entender el concepto coincide, grosso modo, con las construcciones doctrinarias como la elaborada por Aguiló:

(...) la imparcialidad podría definirse como la independencia del juez frente a las partes y el objeto del proceso. Como se ve, estamos apuntando en la misma dirección de antes: imparcial será el juez que aplica el derecho y que lo hace por las razones que el derecho le suministra. En este sentido, los procesalistas suelen distinguir entre lo que llaman "garantías objetivas" y "garantías subjetivas" de la imparcialidad. Las objetivas están vinculadas a la legalidad de la decisión (en nuestra interpretación, deber de aplicar el derecho), 
y las subjetivas a las características del juez llamado a decidir en nuestra interpretación deber de actuar conforme a derecho por las razones que el derecho suministra (Aguiló, 2003, p. 75).

Por otro lado, el segundo de esos conceptos o la neutralidad judicial, que sí es una característica propia del principio acusatorio y del sistema adversarial, supone que al juez como director del proceso "se le exige centralmente neutralidad (equidistancia) respecto de las partes en conflicto, de forma que las decisiones que toma no prejuzguen el resultado del proceso y mantengan el equilibrio entre ellas" (Aguiló, 2003, p. 78).

Así las cosas, son distintos los conceptos de imparcialidad y neutralidad: el primero, supone que el juez cuando decide el conflicto lo debe hacer en atención con equilibrio y con la debida conducción del juicio, esto es, él está comprometido con la verdad de los hechos y la corrección de la decisión; el segundo, supone que el juez debe ser equidistante respecto de las partes en conflicto, de tal forma que las decisiones adoptadas por él no supongan un prejuzgamiento en relación con el resultado del proceso y mantengan el equilibrio entre ellas. De nuevo lo explica la doctrina:

En definitiva, la neutralidad se exige al tercero cuando no está llamado a decidir el resultado y la imparcialidad cuando sí está llamado a hacerlo. Por ello la idea de imparcialidad remite a decisiones comprometidas con ciertos criterios de corrección sustantiva. Sin criterios de corrección, sin sustancia, no cabe, hablar de imparcialidad. La imparcialidad no puede ser una cuestión meramente formal o procesal (Aguiló, 2003, p. 78).

Por ello, el concepto de neutralidad aplicado al ámbito probatorio implica una actitud o comportamiento en cuya virtud se le impide al juez inmiscuirse en las labores probatorias que por su naturaleza le competen en exclusiva a las partes, con lo cual se cuida de un conocimiento previo o con prejuicios anteriores al momento en que el debate probatorio acaece (véase, Congreso de la República, Ley 906, 2004, art. 361). Por ello, al ocuparse del asunto la jurisprudencia emanada de la Sala de Casación Penal de la Corte Suprema de Justicia que pareciera confundir imparcialidad con neutralidad, expresa:

Gravita en torno del principio de imparcialidad, muy caro a los sistemas con tendencia acusatoria, que el Juez no tenga facultades probatorias autónomas, puesto que, si tuviese atribución para decretar pruebas 
de oficio, se daría al traste con uno de los pilares fundamentales de ese régimen de enjuiciamiento, consistente en la definitiva separación entre actos de investigación y actos de juzgamiento, que es emblemático de las democracias contemporáneas, con el fin de evitar que el Juez predisponga el rumbo del proceso, y por ende anticipe su convicción o pierda la ecuanimidad, como podría suceder si dirige o reorienta el destino final del asunto a través de su injerencia en el tema probatorio. (2006, p. 34).

Y añade que permitirle al juez iniciativa probatoria desquiciaría el esquema contentivo del régimen de enjuiciamiento adoptado, eliminando uno de los elementos estructurales del principio, la separación entre los actos de investigación y los de juzgamiento, para permitir que el juez participe de manera activa en el decreto de pruebas, lo cual acarrearía su parcialización frente al asunto al anticipar su postura de acuerdo al desarrollo probatorio. Sin embargo, se asevera que tal prohibición no es absoluta puesto que de acuerdo a los fines constitucionales al juez le atañe, como director del juicio, el interés público traducido en la necesidad que se investiguen los delitos, se encuentre y se conozca la verdad real, se sancione a los responsables y se indemnice o repare a la víctimas del injusto. De igual manera, precluir las investigación y absolver a los inocentes si es el caso.

Por su parte, para la Corte Constitucional el proceso -en el marco del debido proceso-exige que el juez además de ser competente y anterior al acto imputado, sea imparcial, lo cual repercute en su neutralidad, es decir la no dirección material del proceso, con lo cual se permite afianzar el sistema acusatorio, caracterizado por ser adversarial, contradictorio, en condiciones de igualdad y ante juez imparcial (Sentencia C-600, 2011). De allí que, al retomar a la más calificada doctrina, se hable de la imparcialidad en dos esferas: la primera subjetiva, en virtud de la cual, el juez luce como independiente, recto, ecuánime, sin inclinar los intereses de alguna de las partes para favorecer o perjudicar de manera intencional, en cuyo caso el impedimento o la recusación verificará la situación; $y$, la objetiva, en el entendido que no quepa duda sobre su imparcialidad desde la óptica funcional y orgánica (Corte Constitucional, Sentencia C-396, 2007).

Pareciera, pues, aceptarse que una cosa es la imparcialidad judicial entendida como el proceder recto, ecuánime, ajustado a la Carta Política y la ley del operador jurídico y, otra, la neutralidad judicial o pasividad probatoria, en virtud de la que el juez debe estar maniatado para decretar pruebas de oficio, con ello se asegura 
la estructura adversarial, de partes, en igualdad de armas y ante un juez neutral. En otras palabras: en la imparcialidad, el juez, ya sea civil, penal, contencioso o de otra índole, debe auto someterse al principio de legalidad de acuerdo al proceso debido signado en la Constitución, el cual garantiza la visión objetiva en todo momento desde el inicio del proceso hasta la sentencia, la cual de igual manera debe corresponder al principio de congruencia. No obstante, esa corporación termina por confundir ambos conceptos cuando asevera:

El concepto de imparcialidad en el modelo penal acusatorio pasó a ser sinónimo del concepto de neutralidad cognoscitiva del juez, lo cual responde al esquema procesal que escogió el Constituyente con la introducción del sistema penal acusatorio en el Acto Legislativo número 3 de 2002 (Corte Constitucional, Sentencia C-396, 2007).

Ahora bien, por ser el principio de congruencia uno de los elementos característicos del principio acusatorio, resulta importante ocuparse de él para entender sus alcances en el proceso penal y verificar si el mismo se respeta o no en el derecho nacional.

\section{El principio de congruencia.}

En el proceso debe existir una relación de consonancia muy clara entre la acusación y la sentencia, característica que se identifica con el principio acusatorio (Armenta, 1995, p. 72). Al respecto, recuérdese que tanto el artículo $8^{\circ}$ de la Convención Americana sobre Derechos Humanos (adoptada mediante ley 16 de 1972), como el artículo 14 del Pacto Internacional de Derechos Civiles y Políticos (adoptado mediante ley 74 de 1968), señalan la necesidad de sustanciación de la acusación como derecho del acusado, axioma Internacionalmente conocido como el principio de coherencia o de correlación que, como se dice en la sentencia proferida por la Corte Interamericana de Derechos Humanos el 20 de junio de 2005 (Caso Fermín Ramírez Vs. Guatemala, párr. 67 y 68), está íntimamente relacionado con el derecho de defensa, pues el acusado tiene derecho a conocer de manera clara, detalla y circunstanciada, los hechos por los cuales es acusado y ello marca el punto de referencia de la actuación defensiva, siendo inmutables los hechos de la acusación pero sí la calificación jurídica, ésta última siempre y cuando se respeten las garantías para la variación. En el mismo sentido se pronuncia el Tribunal Europeo de Derechos Humanos (Caso de Pelissier y Sassi Vs. Francia, 1999, párr. 62 y 63), en el cual abordó la necesidad de 
conocer la variación de la calificación puesto que al pretermitirse tal situación se advierte conculcación del derecho de defensa.

Ahora bien, desde la Teoría General del Proceso el principio de congruencia es entendido como la regla que condiciona la competencia de las autoridades judiciales, supeditando su decisión respecto a lo solicitado por las partes, de tal manera que no pueden existir fallos ultra ni extrapetita, salvo las excepciones legales, verbi gratia en materia laboral donde el juez puede fallar lo no pedido y más allá de lo pretendido por las partes ${ }^{4}$. En materia penal, el principio es una garantía constitucional y legal que se infiere de los artículos 29, 31 y 250 de la Constitución, y 448 del Código de Procedimiento Penal: "Congruencia. El acusado no podrá ser declarado culpable por hechos que no consten en la acusación, ni por delitos por los cuales no se ha solicitado condena".

El precepto legal citado condiciona la declaración de culpabilidad a la solicitud de parte, sin la cual (en caso de mediar solicitud de sentencia absolutoria) el juzgador no podrá proferir fallo condenatorio. Y es apenas entendible que suceda: la fiscalía detenta el poder punitivo del Estado y es el titular de la acción penal, razón por la cual es quien debe configurar la imputación fáctica y jurídica de los hechos por los cuales se solicita condena; presupone, pues, la existencia de una acusación pero limita el campo de acción de la sentencia a los hechos plasmados en la acusación e impide que la persona sea condenada por delitos no enrostrados por el fiscal.

Así las cosas, se tiene que dicho principio permite la estricta correlación entre la acusación y la sentencia, que conlleva a la vinculación judicial con el objeto del proceso, lo cual repercute en el principio acusatorio, como se ha dicho (Armenta, 1995, p. 72). El principio de congruencia es, entonces, uno de los ejes centrales del sistema penal acusatorio; por ello, en países como Italia, Portugal y Alemania, se resalta la necesidad de: i) determinar los hechos constitutivos de la acusación de manera inequívoca y, ii), la garantía de los derechos de defensa y de contradicción del procesado, preservando bajo determinadas situaciones la posibilidad de modificar la calificación jurídica de los hechos (Armenta, 1995, p. 80).

Añádase, que el principio de congruencia guarda íntima relación con el derecho de defensa en el entendido de que la defensa no solo debe conocer los hechos de la acusación sino que, además, ha de ser informado de la calificación dada a los mismos, puesto que la estrategia defensiva irá encaminada a desvirtuar los cargos enros- 
trados por el fiscal, de tal manera que si no se conoce la calificación se impediría ejercer la defensa en términos garantistas (Armenta, 1995, p. 80).

Para la jurisprudencia nacional este postulado gravita en torno a la identificación de la existencia de una relación causal entre la acusación y la sentencia, que se extiende a la correspondencia entre la audiencia de imputación y la de la formulación de acusación, por lo que es inadmisible la incorporación de nuevos hechos no contenidos en las audiencias previas (Corte Constitucional, Sentencia C-025, 2010). No obstante, se señala que la variación de la calificación jurídica se justifica cuando se buscan los fines del proceso, la justicia y la verdad, o se quiere preservar el deber del estado de investigar los delitos puesto que se torna en provisional, es decir, que puede ser modificada dentro de las pautas establecidas, bien sea en primera o segunda instancias (Corte Constitucional, Sentencia C-025, 2010).

Es más, se ha estudiado el comportamiento del principio comentado en cada uno de los sistemas procesales precedentes, para afirmar que el Decreto 2700 de 1991 y la Ley 600 de 2000 permitían que la calificación jurídica fuera provisional, y que esto no afectaba el derecho de defensa; incluso, se ha señalado que en vigencia de las normas citadas no se aceptaba que la acusación fuera invariable, aclarando que la defensa tenía la oportunidad de modificar sus tesis (Sobre ello, se construyó una línea jurisprudencial clara como se infiere de las sentencias C-491, 1996; C-541, 1998; C- 620, 2001; y, C-1288, 2001).

Por su parte, la Corte Suprema de Justicia en sendos pronunciamientos (Sala de Casación Penal, Sentencia de 28 de noviembre de 2007, radicado: 27.518) se ha ocupado del asunto en los siguientes términos: a) el principio supone el derecho del acusado a conocer la acusación, en cuanto a los hechos y a la calificación jurídica, es decir, la conducta atemperada a la calificación jurídica que de ellos realice la fiscalía; b), se aplica tanto en el proceso que termina con sentencia como en todas los eventos de terminación abreviada del mismo cuando, por ejemplo, hay una aceptación de cargos (pues se debe confrontar los hechos de la formulación de imputación y acusación); $\mathrm{y}, \mathrm{c}$ ) en los casos de allanamiento a cargos se debe verificar que los hechos de la imputación con la cual se allanó sean los mismos que se incluirían en la acusación (Sala de Casación Penal, Sentencia de 20 de octubre de 2005, radicado: 24026). 
Ese organismo agrega que se puede infringir el postulado por acción u omisión en los eventos de proferirse condena por hechos o por delitos diferentes a los señalados por el acusador en la imputación y en la acusación, o cuando se solicite condena por un delito adicionando agravantes no enunciados desde la imputación o acusación, o al desconocer situaciones de menor punibilidad incluidas en dichas etapas (Sentencia de seis de abril de 2006, radicado: 24668). Es más, señala que, en caso del retiro de los cargos por parte de la fiscalía como titular de la acción penal, la decisión del juez queda condicionada a ese comportamiento procesal de tal manera que, si aquel pide sentencia absolutoria, el juez deberá absolver (Corte Suprema de Justicia. Sala de Casación Penal, sentencias de 20 de octubre de 2005, radicado: 24.026, 29 de junio de 2006, radicado: 24.529; trece de julio de 2006, radicado: 15.843; 27 de julio de 2007, radicado: 26468; 28 de marzo de 2012, radicado: 36.621; siete de diciembre de 2011, radicado: 37.211; y 21 de marzo de 2012, radicado: 38.256 ).

Esta última postura ha sido muy discutida desde la óptica del derecho foráneo; por ejemplo, se ha debatido en la Argentina lo sucedido luego de que el Tribunal -tras anular varias sentencias- profirió fallo condenatorio pese a la solicitud de absolución por parte del Ministerio Fiscal (Mendoza, 2009, p. 149-171).

De igual manera, el juez respetuoso del principio de legalidad, sin exacerbar su rol y dentro de los límites de variabilidad de la calificación jurídica manifestada por la fiscalía, le es permitido hacer menos gravosa la calificación jurídica, respetando el contenido de la acusación, pero no podrá agravar su situación; y, en cuanto a la sentencia, se entiende que es un acto complejo, inescindible, que inicia con el sentido del fallo y la sentencia, por tanto la congruencia se predica de ellas (Sala de Casación Penal. Sentencia del 17 de septiembre de 2007, radicado: 27.336). Así las cosas, pareciera que en apariencia el derecho vigente respeta el principio acusatorio en este particular aspecto, aunque una práctica contraria a los dictados de la propia ley y la Constitución pareciera indicar que ello no es así.

\section{Conclusiones}

Después del análisis anterior, enderezado a auscultar los componentes propios del principio acusatorio en el modelo procesal penal adoptado por el legislador, se puede concluir que: 
El principio acusatorio es el elemento estructural del sistema penal acusatorio.

El proceso penal colombiano no se corresponde con un sistema penal acusatorio sino con uno adversarial, con un proceso modulado, que responde a las necesidades y estructura del ordenamiento jurídico de Colombia.

Su concepción, si bien discrepa con el modelo puro, encuentra expreso asidero en la Constitución con lo que se presume que su estructura no riñe con la Carta Política ni con ordenamiento interno.

La Corte Constitucional a través de sus pronunciamientos ha constitucionalizado aún más el modelo, sin embargo las sentencias de la Sala de Casación Penal de la Corte Suprema de Justicia, en sentido estricto, han servido como criterio auxiliar en la mejor interpretación y aplicación del sistema.

La forma como se ha introducido la participación activa del Ministerio Público y de la víctima, ha llevado al desquiciamiento del principio acusatorio y del propio sistema adversarial.

El principio acusatorio no se caracteriza por la imparcialidad jurisdiccional sino por la neutralidad judicial.

Las funciones que en la práctica cumple el Ministerio Público son llevadas a cabo por el juez, quien debe supeditarse al principio de legalidad, por lo cual la participación de ese interviniente en la actuación no aporta nada al sistema; se trataba, en verdad, de cumplir con las cuotas políticas que en su momento se demandaba y con ello se enlodó todo el sistema.

Como lo han dicho tanto la Corte Constitucional como la Sala de Casación Penal de la Corte Suprema de Justicia, el principio de congruencia se torna absoluto en cuanto a la correspondencia de los hechos de la acusación con los narrados en la sentencia, y, provisional o relativo, en tratándose de la calificación jurídica dada, lo cual es aceptado bajo ciertos condicionantes.

La prohibición de decretar pruebas de oficio por parte del juez de conocimiento permite la neutralidad judicial, al impedir la dirección material del mismo en atención a la estructura adversarial; sin embargo, se permite tal facultad al juez de control de garantías para evitar la violación de garantías y derechos de quienes se involucren 
en el trámite puesto en su conocimiento, lo cual -se dice- no lesiona el principio acusatorio pues se trata de audiencias preliminares en las que se decide una materia incidental del proceso, pero no la responsabilidad del acusado.

\section{Notas}

1 Ya en el Código de Procedimiento Penal de 1981 (Decreto 181), sin embargo, se acogía el principio acusatorio (véase artículos 87 y siguientes); este Código no pudo regir ante la declaratoria de inexequibilidad del Acto legislativo 1 de 1979 (Corte Suprema de Justicia, sentencia (1981, noviembre 3). Como precedente suyo, debe mencionarse el Proyecto elaborado por el Profesor Jaime Bernal Cuéllar, que defendía ese mismo principio en sus artículos $7^{\circ}, 12,74$ y ss.; véase, Código de Procedimiento Penal. Ponencia. Bogotá: Librería el Foro de la Justicia, 1980. Así lo explicaba su autor en las 'Explicaciones previas': "(...) desarrolla la institución del Fiscal General de la Nación consagrada en la reforma constitucional, creando, al lado de cada funcionario judicial de las categorías existentes en el momento actual, un fiscal de acusación con funciones concretas en cada una de las etapas del proceso" p. 5). El Acto legislativo 1 de 1979, en su art. 41 disponía: El artículo 144 de la Constitución Nacional quedará así: "La persecución de los delitos, de oficio o mediante denuncia de cualquier persona y la acusación de los infractores ante las autoridades competentes corresponden, en los términos y casos que señale la ley, al Fiscal General de la Nación, quien será el jefe superior de la Policía Judicial. /El Fiscal General dispondrá de los agentes que establezca la ley, con las atribuciones que ésta determine. Tendrán competencia en todo el territorio nacional. / La Cámara de Representantes ejerce determinadas funciones fiscales".

2 Sala de Casación Penal, Sentencia (2006, marzo 30), radicado: 24468. Dice esa decisión: lo cierto es que el Acto Legislativo No. 03 de 2002 introdujo el principio acusatorio, caracterizado por diversos aspectos que coinciden, con algunas variaciones, con los sistemas acusatorios de que habla el derecho comparado, entre ellas: 1.4.1 El Reconocimiento de la "igualdad de armas" entre la fiscalía y la defensa, de modo que puedan actuar en el mismo plano como adversarios que someten su teoría del caso y sus pruebas a conocimiento del juez, encargado de resolver el asunto en justicia. Con la intención de garantizar la defensa en términos adecuados se reconoció al defensor iniciativa probatoria y se ordenó la implementación de un Sistema Nacional de Defensoría Pública, aparejada con el fortalecimiento general de la Defensoría del Pueblo. 1.4.2 La separación entre actos de investigación, acusación y actos de juzgamiento, los cuales son exclusivos y excluyentes, pues, por principio general, el Fiscal no puede decidir con autoridad judicial sobre cuestiones que afecten los derechos fundamentales de los intervinientes, 
ni el Juez puede inmiscuirse en la investigación decretando pruebas de oficio. Este último aserto será desarrollado en un capítulo propio.

3 Cfr. Corte Constitucional, Sentencia C-144 (2010, marzo 3). M. P. Juan Carlos Henao Pérez. Allí se dice: "De la interpretación teleológica y sistemática del Acto Legislativo número 3 de 2002 y de la Ley 906 de 2004, la jurisprudencia y la doctrina coinciden en sostener que dentro de las características claras del sistema penal acusatorio se encuentran, entre otras, las siguientes: i) Separación categórica en las etapas de investigación y juzgamiento. Como consecuencia de ello, desaparece la instrucción como fase de la instancia procesal encomendada al juez y se convierte en una etapa de preparación para el juicio. De esta forma, al juez penal se le encomienda el control de las garantías legales y constitucionales y el juzgamiento mediante el debido proceso oral. ii) El rol del juez en el sistema penal acusatorio está centrado en el control de los actos en los que se requiera ejercicio de la potestad jurisdiccional o que impliquen restricción de derechos o calificación jurídica de los hechos. Así, el control judicial no sólo debe concretarse en el cumplimiento formal de los requisitos sino en la efectividad de los derechos sustanciales en juego. iii) La actuación judicial solamente procede a petición de parte. Así, de acuerdo con el artículo 250 de la Constitución, el ejercicio de la acción penal está a cargo de la fiscalía, quien puede solicitar al juez de control de garantías las medidas necesarias para asegurar la comparecencia de los imputados, la conservación de la prueba y la protección de la comunidad. Esa misma autoridad tiene a su cargo la presentación del escrito de acusación ante el juez de conocimiento, la solicitud de la preclusión de las investigaciones y las medidas necesarias para la protección de las víctimas (250- 4, 5, 6 y 7). iv) El proceso penal es, por regla general, oral, contradictorio, concentrado y público. v) Es posible que el proceso penal no se inicie o se termine pese a la certeza de la ocurrencia de un delito porque existió aplicación del principio de oportunidad o porque hubo acuerdo entre las partes. Por regla general, en los casos de terminación anticipada del proceso, existirá control judicial material y formal de la decisión adoptada. vi) las funciones judiciales del control de garantías y de conocimiento suponen la clara distinción de dos roles para los jueces penales. El primero, el que tiene a su cargo la protección de las garantías y libertades individuales en las etapas preliminares a la imputación y, el segundo, el juez que tiene la responsabilidad de llevar adelante el juicio penal con todas las garantías procesales y sustanciales propias del debido proceso".

4 Devis Echandía, H., (1985). Teoría General del Proceso, t. II, Buenos Aires: Editorial Universidad. Para este autor: es el principio normativo que delimita el contenido de las resoluciones judiciales que deben proferirse, de acuerdo con el sentido y alcance de las peticiones formuladas por las partes (en lo civil, laboral, y contencioso-administrativo) o de los cargos o imputaciones penales formulados contra el sindicado o imputado, 
sea de oficio o por instancia del ministerio público o del denunciante o querellante (en el proceso penal), para el efecto de que exista identidad jurídica entre lo resuelto y las pretensiones o imputaciones y excepciones o defensas oportunamente aducidas, a menos que la ley otorgue facultades especiales para separarse de ellas (p. 533); y añade: "los derechos de acción y de contradicción imponen al Estado el deber de proveer mediante un proceso y por una sentencia, cuyo alcance y contenido están delimitados por las pretensiones y las excepciones que complementan el ejercicio de aquellos derechos" (p. 536).

\section{Referencias}

Abad, J. (2000). El papel del Ministerio Fiscal en el proceso penal español. Ámbito Jurídico, Rio. Recuperado de http:/ / www.ambito-juridico.com. $\mathrm{br} /$ site/index.php?n_link=revista_artigos_leitura\&artigo_id $=5072$

Acto Legislativo 03 de 2002, Por el cual se reforma la Constitución Nacional. Diario Oficial No. 45.040. Congreso de la República de Colombia, diciembre de 2002.

Aguilera, E. (1923). Comentarios a la ley de enjuiciamiento criminal. Madrid: Editorial Reus.

Aguiló, J. (2003). De nuevo sobre 'independencia e imparcialidad de los jueces y argumentación jurídica'. En G. Burgos (Ed), Independencia Judicial en América Latina. ¿De quién? ¿Para qué? ¿Cómo? 1 ed. Bogotá: Colección de Textos de aquí y ahora, ILSA (pp. 65-81).

Alliaud, A. (2001). Principio acusatorio. Estudio histórico-comparado de su génesis y evolución. En E. Hendler. (Ed.), Las garantías penales y procesales. Enfoque histórico-comparado. Buenos Aires: Editores del Puerto (pp. 211-238).

Arbulú, V. (2006). Principio Acusatorio y Debido Proceso: Perspectivas desde el Tribunal Constitucional y la Corte Suprema de la República. Academia de la Magistratura. Recuperado de http://blog.pucp.edu.pe/item/25096/ principio-acusatorio-y-debido-proceso-perspectivas-desde-el-tribunalconstitucional-y-la-corte-suprema-de-la-republica> [citado en dos de marzo de 2014].

Armenta, T. (1995). Principio Acusatorio y Derecho penal. Barcelona: José María Bosch.

Armenta, T. (2004). El proceso penal: fines y características (2 Ed.) MadridBarcelona: Editorial Marcial Pons, Ediciones jurídicas.

Asencio, J. (1991). Principio acusatorio y derecho de defensa en el proceso penal. (1 Ed.) Madrid: Trívium Editorial S. A. 
Baumann, J. (1986). Derecho Procesal Penal. Conceptos fundamentales y principios procesales. Buenos Aires: Depalma.

Benabentos, O. (2005). Teoría General del Proceso 2 (2 Ed.) Rosario: Editorial Juris.

Bernal,J., Montealegre, E. (2013). El Proceso penal. Fundamentos constitucionales y teoría general. $6^{a}$ Ed. Bogotá: Universidad Externado de Colombia.

Bovino, A. (2005). Principios Políticos del Procedimiento Penal. Buenos Aires: Editores del Puerto.

Bovino, A. (1998) Problemas del derecho procesal penal contemporáneo. Buenos Aires: Editores del Puerto.

Bujosa, L. (2004) Principio acusatorio y juicio oral en el proceso penal español. Derecho Penal Contemporáneo, (9) (pp. 55-84).

Bujosa, L. (2009). Prueba de oficio y proceso con todas las garantías. Análisis comparativo de derecho español y colombiano. En J. Almagro et al. (Ed), Rigor Doctrinal y Práctica Forense. (Liber Amicorum) Madrid: Atelier (pp. 233-256).

Burgos, V. (2005). Principios rectores del Nuevo Código Procesal Penal Peruano. Lima: Palestra Editores.

Caso Fermín Ramírez vs. Guatemala, (2005, junio 20). Fondo, reparaciones y costas. Corte Interamericana de Derechos Humanos.

Caso de Pélissier y Sassi v. France, (1999, marzo 25). Reports of Judgments and Decisions, 1999-II. Köln: Carl Heymanns Verlag, s/f. Tribunal Europeo De Derechos Humanos. Recuperado de http://www.echr.coe. int/Documents/Reports_Recueil_1999-II.pdf (pp. 281-345).

Código de Procedimiento Penal, Ponencia. (1980) Bogotá: Librería el Foro de la Justicia.

Cuéllar, R. (2002). La Reforma Procesal Penal y el Ministerio Público en Honduras: Justificación y Perspectivas. Tegucigalpa: Ministerio Público.

Cuéllar, R. (2006). El principio acusatorio en el proceso penal moderno: significado y alcance. Recuperado de http://rigobertocuellar.blogspot. com/2006/08/el-principio-acusatorio-en-el-proceso.html.

De la Oliva, A., Aragonesenes, S., Honjosa, R., Muerza, J. (1999). Derecho Procesal Penal. Madrid: Centro de Estudios Ramón Areces.

Devis, H. (1985). Teoría General del Proceso. T. II, Buenos Aires: Editorial Universidad. 
Díaz, J. (1996). Principios de aportación de parte y acusatorio: la imparcialidad del juez. Granada: Editorial Comares.

Díez-Picazo, L. (2000). El poder de acusar: Ministerio Fiscal y constitucionalismo. (1 Ed). Barcelona: Editorial Ariel S.A.

Díez-Picazo, L. (1997). La configuración jurídico-política de la acusación pública en los Estados Unidos. Tribunales de justicia. Revista española de derecho procesal. ( $\left.N^{o} 3\right)$ (pp. 291-306).

España. Constitución Política (1978). Reino de España. España.

Ferrajoli, L. (1995). Derecho y razón. tr. Perfecto Andrés Ibáñez et al. Madrid: Editorial Trotta. 1995.

Ferreiro, A. (2010). Procesos Inquisitivo, Acusatorio y Mixto. Recuperado de http:/ / es.scribd.com/doc/26298268/Procesos-Inquisitivo-Acusatorioy-Mixto.

Gimeno, V. (1981). Fundamentos del Derecho Procesal Penal. Madrid: Civitas.

Gimeno, V., Moreno, V., Cortés, V. (1999). Derecho Procesal Penal. Madrid: Editorial Colex.

Gómez, J. (2003). El Tribunal penal internacional: investigación y acusación. Valencia: Tirant monografías.

Gómez, J. (2003a). La investigación del crimen en el proceso penal ante el Tribunal Penal Internacional. Revista de Derecho Penal. ( $\left.\mathrm{N}^{\mathrm{o}} 12\right)$, pp. 72-97. Recuperado de http://www.cienciaspenales.net/portal/page/portal/ IDP/REVISTA_PENAL_DOCS/Numero_12/72-98.pdf.

Gómez, J. (2008). El sistema de enjuiciamiento criminal propio de un Estado de Derecho. México: Universidad Jaume I-Instituto Nacional de Ciencias Penales.

Gómez, J. (Coord.) AA.VV., (2013). Introducción al Proceso penal federal de los Estados Unidos de Norteamérica. Valencia: Tirant lo Blanch.

Gómez, E., Herce, V. (1959). Derecho Procesal Penal. (5 Ed.) Madrid: A.G.E.S.A Rustica: Madrid.

González, A. (2001). Correlación entre acusación y sentencia penal. (Tesis doctoral). Universidad de La Laguna. Recuperado de ftp://tesis.bbtk. ull.es/ccssyhum/cs118.pdf.

González, A. (2004). Acusación y defensa en el proceso penal. Barcelona: Bosch.

Guerrero, S. (2009). El Principio acusatorio. (2 Ed.) Cizur Menor (Navarra): Editorial Aranzadi-Thomson. 
Guerrero, O. (2011). Fundamentos teórico constitucionales del nuevo proceso penal. (2 Ed.) Bogotá: Ediciones Nueva Jurídica.

Herrera, J. (2005). El principio Acusatorio. Procuraduría General de la Nación. Recuperado de www.ministeriopublico.gob.pa.

Langbein, J. (2003). The Origins of Adversary Criminal Trial. Oxford Studies in Modern Legal History. New York: Oxford University Press.

Ley 600 de 2000. Código de Procedimiento Penal. Diario Oficial No. 44.097. Congreso de la República de Colombia, julio de 2000.

Ley 906 de 2004. Código de Procedimiento Penal. Diario Oficial No. 45.658. Congreso de la Republica de Colombia, agosto de 2004.

Maier, J. (1998). Derecho Procesal Penal Argentino. T. I. Vol. b. Buenos Aires: Editorial Hammurabi.

Maier, J. (1996). Derecho Procesal Penal. (2 Ed.) Buenos Aires: Editores el Puerto.

Martínez, A. (1992). Principio acusatorio: Teoría general y aplicación práctica. Los principios del proceso penal y la presunción constitucional de inocencia. Cuadernos del Poder Judicial, (No 5), 51-102, Madrid: Consejo General del Poder Judicial, 1992.

Mendoza, J. (2009). La correlación entre la acusación y la sentencia. Una visión americana. IUS. Revista del Instituto de Ciencias Jurídicas de Puebla A.C., (N²4), Puebla: Instituto de Ciencias Jurídicas de Puebla A. C. Puebla. pp. 149-171.

Meza, E. (2009). Principio acusatorio y de oralidad en los juicios relativos a los delitos de delincuencia organizada. Revista del Instituto de la Judicatura Federal, (N²7) (pp. 195-213).

Montero, J. (1992). El principio acusatorio. Un intento de aclaración conceptual. Revista Justicia, ( ${ }^{\circ}$ 4), pp. 775-788.

Montero, J. (1994). La garantía procesal penal y el principio acusatorio. En A. De la Olivia Santos (Ed.), Justicia y Sociedad. Ciudad de México: Universidad Nacional Autónoma de México, Instituto de Investigaciones Jurídicas. pp. 525-546.

Moreno, V.; Cortés y V., Gimeno, V. (2003). Introducción al Derecho procesal. (4 Ed.) Madrid: Colex.

Ordoñez, M. y Cano, D. La Resistencia del sistema penal inquisitivo. Perspectiva histórica. (Tesis doctoral) Universidad Javeriana. Recuperado de http:// hermes.javeriana.edu.co/biblos/tesis/derecho/dere5/TESIS36.pdf. 
Organización de los Estados Americanos [OEA]. (1969). Convención Americana sobre Derechos Humanos suscrita en la conferencia especializada interamericana sobre derechos humanos (B-32). Pacto de San José de Costa Rica. Costa Rica. Recuperado de http://www.oas.org/dil/esp/tratados_B-32_ Convencion_Americana_sobre_Derechos_Humanos.pdf.

Organización de las Naciones Unidas [ONU]. (1948). Declaración Universal de Derechos Humanos. Paris. Recuperado de https://www.un.org/es/ documents/udhr/.

Organización de las Naciones Unidas [ONU]. (1976). Pacto Internacional de Derechos Civiles y Politicos. Recuperado de http://www2.ohchr.org/ spanish/law/ccpr.htm/.

Ortego, F. (2007). Juicio de acusación. Barcelona: Ateliers Libros S. A.

Perú. Constitución Política (1993). Congreso Constituyente Democrático. Perú.

Perú. Caso Manuel Enrique Umbert Sandoval. (2006, Marzo 13). Recurso de agravio constitucional. Tribunal Constitucional de Perú.

Perú. Caso de Ricardo Ernesto Gómez Casafranca (2005, Julio 21). Recurso extraordinario. Tribunal Constitucional de Perú.

Perú. Caso de Jacinta Margarita Toledo Manrique. (2005, Agosto 6). Recurso de agravio constitucional. Tribunal Constitucional de Perú.

Perú. Sentencia 0023-2003-AI/TC (2004, julio 9). Acción de Inconstitucionalidad. Tribunal Constitucional de Perú.

Petrone, M. (1994). El principio acusatorio. En A. De la Olivia Santos (Ed.) Justicia y Sociedad, Ciudad de México: Universidad Nacional Autónoma de México, Instituto de Investigaciones Jurídicas. pp. 503-524.

Pfeffer, E. (2001). Entrada en Vigencia del Nuevo Código Procesal Penal en el País. En Ius et Praxis, Universidad de Talca, Facultad de Ciencias Jurídicas y Sociales, (2), 2001. pp. 259-271. Recuperado de http://www.scielo.cl/ scielo.php?pid=S0718-00122001000200011\&script=sci_arttext.

Proyecto de Acto legislativo 237 de 2002, Exposición de motivos. Por el cual se modifican los artículos 234, 235, 250 y 251 de la Constitución Política. Gaceta del Congreso No. 134 de 2002. Cámara de Representantes.

Rodríguez, M. (2013). Sistema acusatorio de justicia penal y principio de obligatoriedad de la acción penal. Revista de Derecho de la Pontificia Universidad Católica de Valparaíso, 2013, pp. 643 - 686.

Roxin, C. (2000). Derecho procesal penal. tr. Gabriela E. Córdoba y Daniel R. Pastor. Buenos Aires: Editores del Puerto. 
Sentencia C-491 (1996, septiembre 26). Acción pública de inconstitucionalidad. M. P. José Gregorio Hernández Galindo. Corte Constitucional de Colombia.

Sentencia C-541 (1998, octubre 1). Acción pública de inconstitucionalidad. M. P. Alfredo Beltrán Sierra. Corte Constitucional de Colombia.

Sentencia C- 620 (2001, junio 13). Demanda de inconstitucionalidad. M. P. Jaime Araujo Rentería. Corte Constitucional de Colombia.

Sentencia C- 1288 (2001, diciembre 5). Demanda de inconstitucionalidad. M. P. Álvaro Tafur Galvis. Corte Constitucional de Colombia.

Sentencia C-228 (2002, abril 3). Demanda de inconstitucionalidad. M. P. Manuel José Cepeda Espinosa y Eduardo Montealegre Lynett. Corte Constitucional de Colombia.

Sentencia C-873 (2003, septiembre 30). Demanda de inconstitucionalidad. M.P. Manuel José Cepeda Espinosa. Corte Constitucional de Colombia.

Sentencia C-591 (2005, junio 9). Demanda de inconstitucionalidad. M. P. Clara Inés Vargas Hernández. Corte Constitucional de Colombia.

Sentencia C-818 (2005, agosto 9). Demanda de inconstitucionalidad. M. P. Rodrigo Escobar Gil. Corte Constitucional de Colombia.

Sentencia C-979 (2005, septiembre 26). Demanda de inconstitucionalidad. M. P. Jaime Córdoba Triviño. Corte Constitucional de Colombia.

Sentencia C-1154 (2005, noviembre 15). Demanda de inconstitucionalidad. M. P. Manuel José Cepeda Espinosa. Corte Constitucional de Colombia.

Sentencia C-1177 (2005, noviembre 17). Demanda de inconstitucionalidad. M. P. Jaime Córdoba Triviño. Corte Constitucional de Colombia.

Sentencia C-1194 (2005, noviembre 22). Demanda de inconstitucionalidad. M. P. Marco Gerardo Monroy Cabra. Corte Constitucional de Colombia.

Sentencia C-454 (2006, junio 7). Demanda de inconstitucionalidad. M. P. Jaime Córdoba Triviño. Corte Constitucional de Colombia.

Sentencia C-209 (2007, marzo 21). Demanda de inconstitucionalidad. M. P. Manuel José Cepeda Espinosa. Corte Constitucional de Colombia.

Sentencia C-396 (2007, mayo 23). Demanda de inconstitucionalidad. M.P. Marco Gerardo Monroy Cabra. Corte Constitucional de Colombia.

Sentencia C-516 (2007, julio 11). Demanda de inconstitucionalidad. M. P. Jaime Córdoba Triviño. Corte Constitucional de Colombia. 
Sentencia C-186 (2008, febrero 27). Demanda de inconstitucionalidad. M. P. Nilson Pinilla Pinilla. Corte Constitucional de Colombia.

Sentencia C-025 (2009, enero 27). Demanda de inconstitucionalidad. M. P. Rodrigo Escobar Gil. Corte Constitucional de Colombia.

Sentencia C-069 (2009, febrero 10). Demanda de inconstitucionalidad. M. P. Clara Inés Vargas Hernández. Corte Constitucional de Colombia.

Sentencia C-839 (2009, noviembre 20). Acción de tutela. M. P. Jorge Ignacio Pretelt Chaljub. Corte Constitucional de Colombia.

Sentencia C-025 (2010, enero 27). Demanda de inconstitucionalidad. M. P. Humberto Sierra Porto. Corte Constitucional de Colombia.

Sentencia C-144 (2010, marzo 3). Demanda de inconstitucionalidad. M. P. Juan Carlos Henao Pérez. Corte Constitucional de Colombia.

Sentencia C-260 (2011, abril 6). Demanda de inconstitucionalidad. M. P. Jorge Iván Palacio Palacio. Corte Constitucional de Colombia.

Sentencia C-600 (2011, agosto 10). Demanda de inconstitucionalidad. M. P. María Victoria Calle Correa. Corte Constitucional de Colombia.

Sentencia C-881 (2011, noviembre 23). Demanda de inconstitucionalidad. M. P. Luis Ernesto Vargas Silva. Corte Constitucional de Colombia.

Sentencia (2005, octubre 20) radicado: 24.026. M. P. Mauro Solarte Portilla. Corte Suprema de Justicia de Colombia, Sala de Casación Penal.

Sentencia (2006, marzo 30) radicado: 24468. M. P. Edgar Lombana Trujillo. Corte Suprema de Justicia de Colombia, Sala de Casación Penal.

Sentencia (2006, abril 6) radicado: 24.668, M.P. Jorge Luis Quintero Milanés. Corte Suprema de Justicia de Colombia, Sala de Casación Penal.

Sentencia (2006, junio 29) radicado: 24.529, M. P. Jorge Luis Quintero Milanés. Corte Suprema de Justicia de Colombia, Sala de Casación Penal.

Sentencia (2006, julio 13) radicado: 15.843. M. P. Alfredo Gómez Quintero. Corte Suprema de Justicia de Colombia, Sala de Casación Penal.

Sentencia (2007, septiembre 17) radicado: 27.336. M. P. Augusto J. Ibáñez Guzmán. Corte Suprema de Justicia de Colombia, Sala de Casación Penal.

Sentencia (2007, noviembre 28) radicado: 27.518, M. P. Julio E. Socha Salamanca. Corte Suprema de Justicia de Colombia, Sala de Casación Penal.

Sentencia (2011, diciembre 7) radicado: 37.211. M. P. Augusto J. Ibáñez Guzmán. Corte Suprema de Justicia de Colombia, Sala de Casación Penal. 
Sentencia (2012, marzo 21) radicado: 38.256. M. P. Augusto J. Ibáñez Guzmán. Corte Suprema de Justicia de Colombia, Sala de Casación Penal.

Sentencia (2012, marzo 28) radicado: 36.621. M. P. Augusto J. Ibáñez Guzmán. Corte Suprema de Justicia de Colombia, Sala de Casación Penal.

Tomás y Valiente, F. (1980). Relaciones entre la inquisición con el aparato institucional del Estado, en la inquisición española. Madrid: Siglo XXI Editores.

Vásquez, J. (1984). El principio acusatorio y su reflejo en el proceso penal español. Homenaje a la Ley de Enjuiciamiento Criminal tras cien años de vigencia. Revista Jurídica de Catalunya, 83 (2) (pp. 373-418).

Vélez, A. (1956). Estudios de Derecho Procesal Penal. Córdoba: Imprenta de la Universidad de Córdoba.

Vergé, J. (1994). La Defensa del imputado y el principio acusatorio. Barcelona: J. M. Bosch Editor.

Vlastos, G. (1946). Solonian justice. Classical Philology, 12(2), pp. 65 y ss. Chicago: University of Chicago Press. Recuperado de http://www. jstor.org $/$ discover $/ 10.2307 / 267356$ ? uid $=3737808 \&$ uid $=2 \& u i d=4 \&$ s $\mathrm{id}=21103657592123$.

Zamora, J. (1994). El principio acusatorio. En A. De la Olivia Santos (Ed.) Justicia y Sociedad, Ciudad de México: Universidad Nacional Autónoma de México, Instituto de Investigaciones Jurídicas (pp. 563-573). 
